\title{
Significance of ROS in oxygen sensing in cell systems with sensitivity to physiological hypoxia
}

\author{
Constancio Gonzalez*, Gloria Sanz-Alfayate, M. Teresa Agapito, \\ Angela Gomez-Niño, Asunción Rocher, Ana Obeso \\ Departamento de Bioquímica y Biologia Molecular y Fisiología, Facultad de Medicina, \\ Instituto de Biología y Genética Molecular (IBGM), Universidad de Valladolid y CSIC, 47005 Valladolid, Spain
}

Accepted 28 August 2001

\begin{abstract}
Reactive oxygen species (ROS) are oxygen-containing molecular entities which are more potent and effective oxidizing agents than is molecular oxygen itself. With the exception of phagocytic cells, where ROS play an important physiological role in defense reactions, ROS have classically been considered undesirable byproducts of cell metabolism, existing several cellular mechanisms aimed to dispose them. Recently, however, ROS have been considered important intracellular signaling molecules, which may act as mediators or second messengers in many cell functions. This is the proposed role for ROS in oxygen sensing in systems, such as carotid body chemoreceptor cells, pulmonary artery smooth muscle cells, and erythropoietin-producing cells. These unique cells comprise essential parts of homeostatic loops directed to maintain oxygen levels in multicellular organisms in situations of hypoxia. The present article examines the possible significance of ROS in these three cell systems, and proposes a set of criteria that ROS should satisfy for their consideration as mediators in hypoxic transduction cascades. In none of the three cell types do ROS satisfy these criteria, and thus it appears that alternative mechanisms are responsible for the transduction cascades linking hypoxia to the release of neurotransmitters in chemoreceptor cells, contraction in pulmonary artery smooth muscle cells and erythropoietin secretion in erythropoietin producing cells. C) 2002 Elsevier Science B.V. All rights reserved.
\end{abstract}

Keywords: Carotid body, signal transduction; Control of breathing, $\mathrm{O}_{2}$ sensing; Mediators, erythropoietin; Mediators, ROS; Oxygen, cellular sensing; Signal transduction, carotid body, erythropoietin cell, pulmonary vasculature

\footnotetext{
* Corresponding author. Tel.: + 34-983-423-089; fax: + 34983-423-588

E-mail address: constanc@ibgm.uva.es (C. Gonzalez).
}

\section{Cell systems with sensitivity to physiological hypoxia}

The appearance of $\mathrm{O}_{2}$ on a previously anaerobic earth, forced living organisms to develop antioxidant defense systems. Organisms that evolved tolerance to $\mathrm{O}_{2}$ also developed mechanisms to use this new element for metabolic transformations 
and efficient energy production by using electron transport chains with $\mathrm{O}_{2}$ as the final electron acceptor. The development of efficient and secure energy production systems allowed the appearance of multicellular organisms. The acquisition of $\mathrm{O}_{2}$ and nutrients by diffusion from the surrounding aqueous medium was succeeded in multicellular organisms by the appearance of a circulatory system, a system of tubes to carry and to distribute $\mathrm{O}_{2}$ and nutrients among all cells of the living organism. Evolution later provided an oxygenating or respiratory system capable of supplying $\mathrm{O}_{2}$ to the fluid moving in the circulatory system, and the moving fluid itself evolved to blood to gain in capacity to transport $\mathrm{O}_{2}$. All these acquisitions provided living organisms with the independence necessary to abandon water and to move freely on land. Nevertheless, full acquisition of terrestrial freedom was only possible by the simultaneous appearance of homeostatic mechanisms. Some of those homeostatic mechanisms match $\mathrm{O}_{2}$ supply to whole-body energetic needs, by monitoring $\mathrm{O}_{2}$ levels in the body, and altering the overall function of the respiratory and circulatory systems, as well as the capacity of blood to transport $\mathrm{O}_{2}$.

There are two main systems regarding $\mathrm{O}_{2}$ homeostasis. They conform two functional loops with their origin in the $\mathrm{O}_{2}$-monitoring cells, the chemoreceptor cells of the carotid body (CB) and the erythropoietin (EPO)-producing cells (Richalet, 1997; Gonzalez, 1998). These two cell types are receptor-effector units, which detect arterial blood $\mathrm{O}_{2}$ levels and respond with a secretory response. The functional loop originated in the $\mathrm{CB}$ works as follows: Chemoreceptors cells detect arterial blood $\mathrm{P}_{\mathrm{O}_{2}}$ and become activated when arterial $\mathrm{P}_{\mathrm{O}_{2}}$ decreases; they release neurotransmitters which activate the sensory nerve endings of the carotid sinus nerve, whose central projections end in the nucleus of the tractus solitarius in the medulla. Integration of the carotid sinus nerve input in the respiratory control centers of the brain stem results in an increased activity of the respiratory muscles, with increased ventilation and increased alveolar and arterial blood $\mathrm{P}_{\mathrm{O}_{2}}$ (Gonzalez et al., 1992, 1994). EPO-producing cells, which in adult animals are mainly located in the kidney, also detect arterial blood $\mathrm{O}_{2}$ levels and are activated by hypoxia to release EPO; this glycoproteic hormone reaches the bone marrow and activates erythropoiesis. An increase in the red blood cell mass and ultimately in the capacity of the blood to transport $\mathrm{O}_{2}$ follow (Jelkmann, 1992). These two systems probably are aided in maintaining the homeostasis of $\mathrm{O}_{2}$ by the pulmonary artery smooth muscle cells (PASMC), which, as the other cell two types, monitor oxygen levels and react to hypoxia with a contractile response leading to vasoconstriction and lung blood flow redistribution which would ameliorate the oxygenation of blood (Marshall et al., 1994). We have previously defined physiological hypoxia and these three cell types as endowed with sensitivity to physiological hypoxia (Gonzalez, 1998).

These three cell systems, contributing to the homeostasis of $\mathrm{O}_{2}$, share other properties. They have a very low threshold to hypoxia, becoming activated at an arterial $\mathrm{P}_{\mathrm{O}_{2}}$ of $\approx 70 \mathrm{mmHg}$ and increasing their effector activity with the intensity of hypoxia. In contrast, the response to hypoxia in most cells is a decrease in their activity (Hochachka et al., 1997) and as the hypoxic threshold for this behavior is higher, a more intense hypoxia is needed to elicit it. The different behavior of the cell types involved in homeostatic loops versus general cells of the organism allows to predict that the detection of $\mathrm{O}_{2}$ levels (i.e. $\left(\mathrm{O}_{2}\right.$-sensing), if linked to $\mathrm{O}_{2}$-consumption rate, should be associated to an increase of $\mathrm{O}_{2}$-consumption in the case of the cells involved in homeostatic loops and to a decrease in the rest of the cells. The increase in $\mathrm{O}_{2}$-consumption during hypoxia in the former cells is an absolute requirement to support the increased activity they exhibit in these circumstances; the decrease in $\mathrm{O}_{2}$-consumption during hypoxia in the rest of the cells is inferred from the near shutdown of all energy-requiring processes. Alternatively, $\mathrm{O}_{2}$-sensing could be independent of $\mathrm{O}_{2}$-consumption rate in both categories of cells. Whatever the case, there are experimental observations supporting the contention that the cell types involved in homeostatic loops, as exemplified by the $\mathrm{CB}$ chemoreceptor cells, exhibit an increased metabolic rate and $\mathrm{O}_{2}$ consumption during hypoxia. Thus, ATP levels are not significantly different in normoxia and moderate hypoxia (Verna et al., 1990), and at the same time, hypoxia of comparable intensity in- 


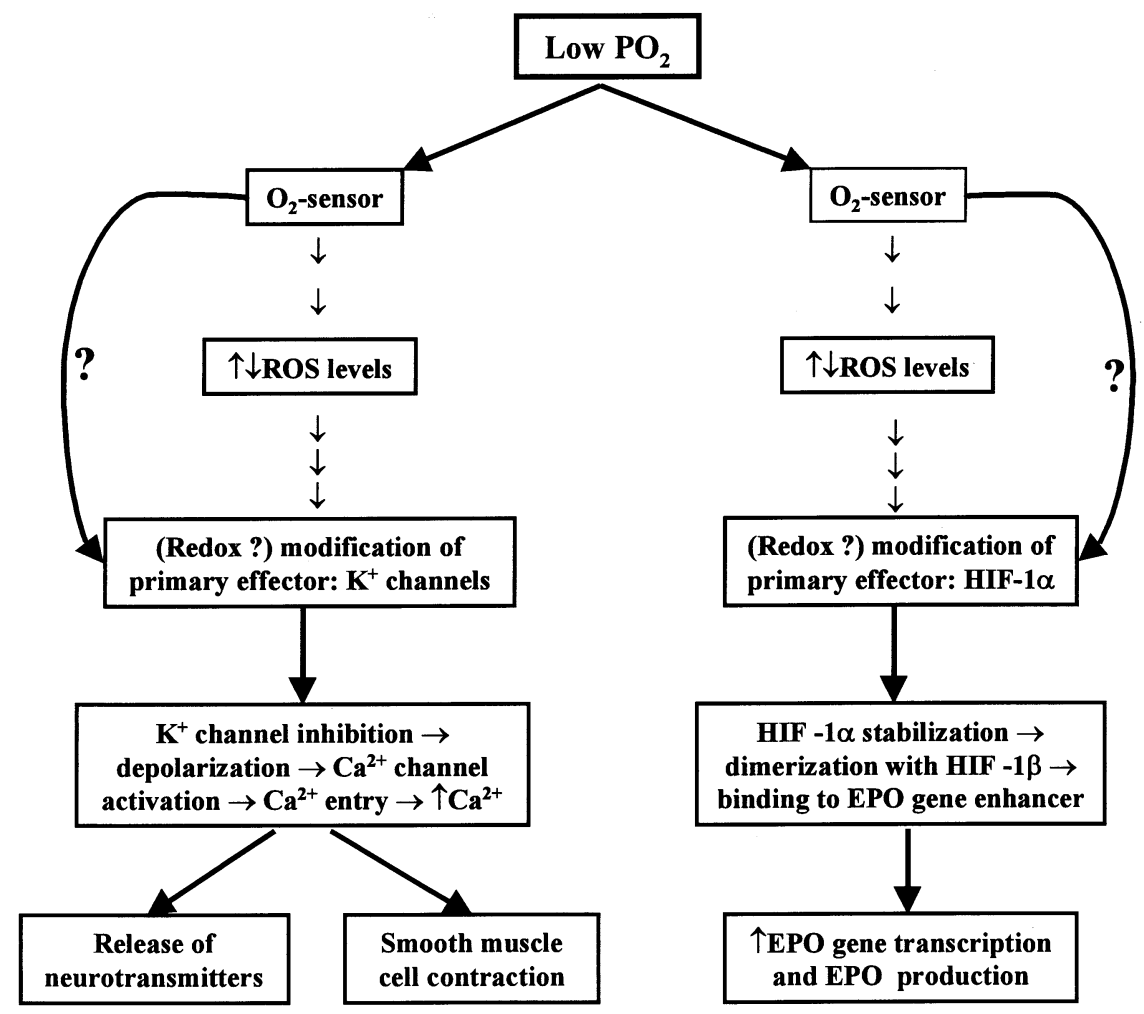

Fig. 1. Redox models for oxygen sensing in the three cells systems located at the origin of oxygen homeostatic loops. The top lateral arrows with question marks represent alternative oxygen sensing models (e.g. hemoprotein sensing) not discussed in this article.

creases glucose oxidation to $\mathrm{CO}_{2}$ in an ouabaindependent manner (Obeso et al., 1989b, 1993).

An alternative way of stating the notions expressed in previous paragraphs is to say that in higher organisms there are a few cell systems devoted to maintaining $\mathrm{O}_{2}$ levels in the entire organism which appear to have a unique mechanism for $\mathrm{O}_{2}$-sensing. The uniqueness of this $\mathrm{O}_{2}$ sensing mechanism refers to its threshold and to its ability to become coupled to and to activate cell processes demanding an energy supply. This article will consider the redox models of $\mathrm{O}_{2}$-sensing. We shall discuss the available information in favor and against the participation of oxygen reactive species (ROS) in $\mathrm{O}_{2}$-sensing and the possible significance of ROS as coupling factors between hypoxia and the effector machinery of the cells involved in the homeostasis of oxygen (Fig. 1).

\section{Free radicals, oxygen reactive species (ROS) and allied molecules}

\subsection{Primary free radicals}

Free radicals are chemically defined as atoms or molecules that have one or more unpaired electron; they usually are very reactive (Punchard and Kelly, 1996; Halliwell and Gutteridge, 1999). The primary processes that give rise to free radicals in biological systems are divided into two main categories. Due to the high water content of living organisms, the cleavage of the chemical bonds of water by high-energy radiation (water radiolysis) constitutes an important source of free radicals according to the reaction:

$$
\begin{aligned}
\mathrm{H}_{2} \mathrm{O} \rightarrow & \mathrm{H}^{\bullet} \text { (hydrogen radical) } \\
& +\mathrm{OH}^{\bullet} \text { (hydroxyl radical) }
\end{aligned}
$$


Ultraviolet light and even visible light in the presence of some sensitizer molecules can similarly produce homolytic scission of hydrogen peroxide in the skin to generate hydroxyl radicals $\left(\mathrm{H}_{2} \mathrm{O}_{2} \rightarrow 2 \mathrm{OH}^{\circ}\right)$. More important, however, (at least quantitatively) is the genesis of free radicals by reactions involving the transference of electrons, and among them the most important are those reactions in which a single electron is transferred to a molecule of $\mathrm{O}_{2}$ to form the superoxide radical, $\mathrm{O}_{2}^{-\bullet}$ (Davies and Dean, 1997). Phagocytes possess an enzymatic complex containing FAD and a specific b-type cytochrome capable of taking an electron from NADPH and transferring it to $\mathrm{O}_{2}$ to form $\mathrm{O}_{2}^{-}$. This is probably the only reaction in which $\mathrm{O}_{2}^{-}$is a beneficial product; this radical and other ROS formed from it are used by phagocytic cells to kill bacteria. There are, however, many unwanted processes producing $\mathrm{O}_{2}^{-}$as a byproduct, some of which are briefly commented here. There are auto-oxidation reactions in which several biologically important molecules such as tyrosine, catecholamines and tryptophan slowly reduce $\mathrm{O}_{2}$ to form $\mathrm{O}_{2}^{-} \cdot \mathrm{O}_{2}^{-}$in turn is capable of further oxidizing those molecules and a cascade of reactions might be started with potentially deleterious effects. Microsomal enzymes involved in reactions of oxidation and hydroxylation of many types of molecules (alcohols, barbiturates, antibiotics, steroid hormone synthesis and metabolism, etc.), which use cytochrome P450 as an electron transport system, can also generate $\mathrm{O}_{2}^{-}$. Superoxide radical is also formed in the transport of $\mathrm{O}_{2}$ by hemoglobin. Although essentially all $\mathrm{O}_{2}$ binding to hemoglobin (and myoglobin) does not imply the oxidation of $\mathrm{Fe}^{2+}$ in the heme moiety, there is, however, a certain degree of delocalization of an electron when $\mathrm{O}_{2}$ is bound and thereby the appearance of some kind of intermediate structure that can be written as an apparent resonant 'equilibrium': hemo- $\mathrm{Fe}^{2+}-\mathrm{O}_{2} \leftrightarrow$ hemo- $\mathrm{Fe}^{3+}-\mathrm{O}_{2}^{-} \cdot$. Usually, the $\mathrm{Fe}^{2+}$ of heme group keeps the delocalized electron and hemoglobin releases $\mathrm{O}_{2}$, but occasionally ( $3 \% /$ day) the electron is kept by $\mathrm{O}_{2}$ and hemoglobin then releases $\mathrm{O}_{2}^{-} \cdot$, the $\mathrm{Fe}^{2+}$ of the heme group is transformed into $\mathrm{Fe}^{3+}$ and methemoglobin is formed. In situations of tissue injury, especially in the processes of ischemiareperfusion, the enzyme xanthine dehydrogenase which oxidizes hypoxanthine and xanthine to uric acid using $\mathrm{NAD}^{+}$as acceptor of electrons, is modified by oxidative or proteolytic processes and converted into xanthine oxidase, which is capable of transferring the electrons of the purines to $\mathrm{O}_{2}$ to form $\mathrm{O}_{2}^{-}$. However, there is no doubt that quantitatively speaking the most important source of $\mathrm{O}_{2}^{-}$is the mitochondrial electron transport chain, where univalent reduction of $\mathrm{O}_{2}$ may take place in some steps of the overall transport system (Fig. 2). In the two places where $\mathrm{O}_{2}^{-}$can be produced (complex I and ubiquinone pool) there are electron shuttle molecules (flavin adenin mononucleotide and ubiquinone), which can accept one or two electrons. When they accept a single electron they become free radical molecules themselves capable of slipping the electron to molecular $\mathrm{O}_{2}$. It is estimated that a small percentage $(<5 \%)$ of the total $\mathrm{O}_{2}$ consumed by mitochondria at normal $\mathrm{P}_{\mathrm{O}_{2}}$ is converted to $\mathrm{O}_{2}^{-}$.

To complete this overview on radicals it remains to say some words on reactive nitrogen species. Nitric oxide or nitrogen monoxide ( $\mathrm{NO}^{\circ}$ ) is a free radical as it has one unpaired electron. It is a gas molecule capable of freely diffusing through cell membrane systems. $\mathrm{NO}^{\bullet}$ is physiologically synthesized by a family of different nitric oxide synthases from the amino acid L-arginine. It binds to $\mathrm{Fe}^{2+}$ of heme groups, and in fact many of its physiological actions are mediated by the soluble guanylate cyclase, which is a hemoprotein that synthesizes cGMP, although cyclase independent physiological effects have been described (Archer et al., 1994; Bolotina et al., 1994; Ohkuma and Katsura, 2001). Due to its ability to react with heme groups, NO can inhibit cytochrome oxidase competitively with $\mathrm{O}_{2}$ (Boveris et al., 2000). In body fluids $\mathrm{NO}^{\bullet}$ reacts with $\mathrm{O}_{2}$ to give the more reactive radical nitrogen dioxide $\left(2 \mathrm{NO}^{\circ}+\mathrm{O}_{2} \rightarrow 2 \mathrm{NO}_{2}{ }^{\circ}\right)$, but largely it is oxidized to nitrite ion $\left(4 \mathrm{NO}^{\circ}+\mathrm{O}_{2}+2 \mathrm{H}_{2} \mathrm{O} \rightarrow 4 \mathrm{NO}_{2}^{-}\right)$or reacts with the heme groups of oxyhemoglobin to form metahemoglobin and $\mathrm{NO}_{3}^{-}$(nitrate). In fact, the evaluation of $\mathrm{NO}^{\bullet}$ synthesis in vivo is quite frequently assessed by the measurement of nitrite and nitrate levels. 


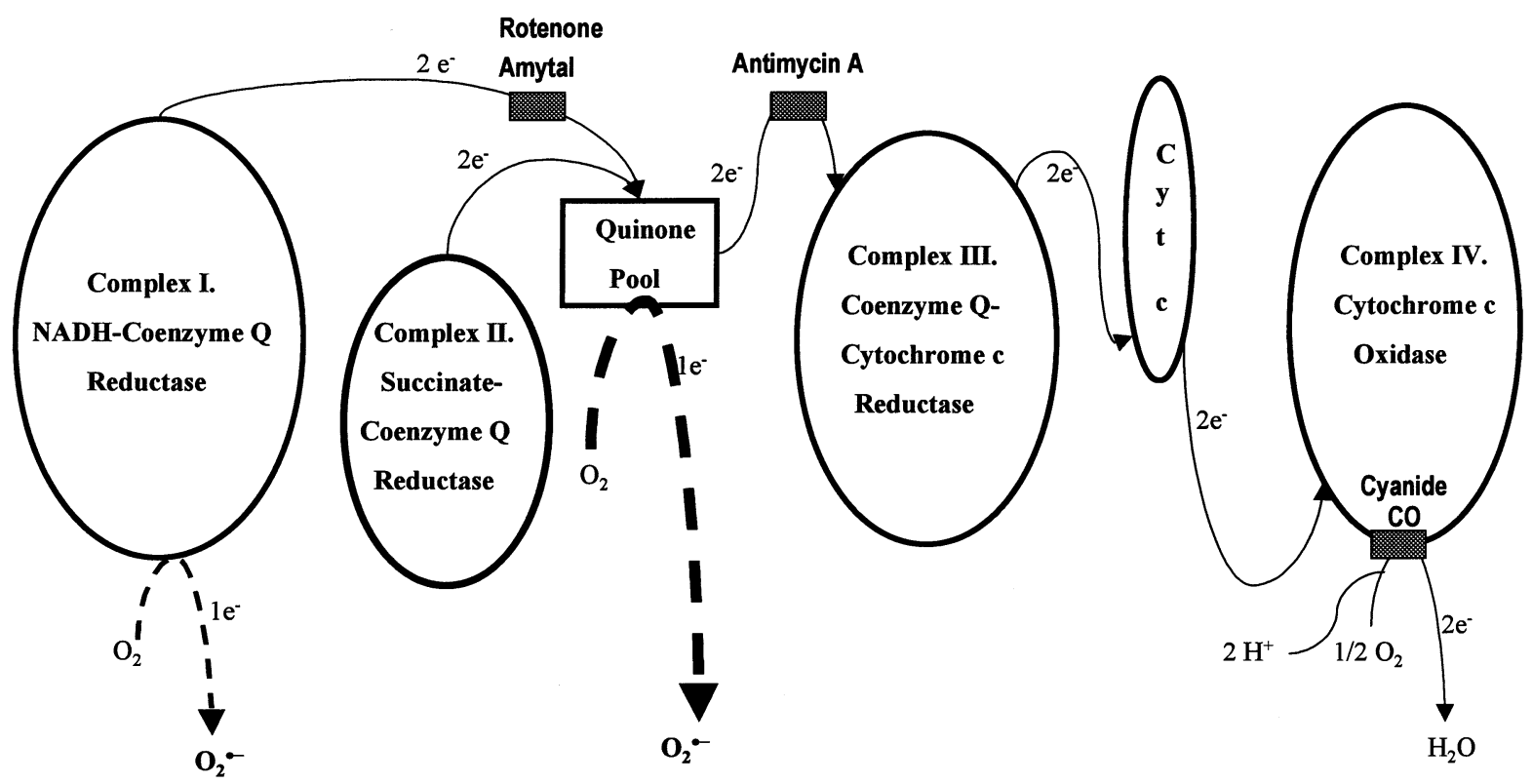

Fig. 2. General schema of the mitochondrial respiratory chain illustrating the loci where $\mathrm{O}_{2}^{-}{ }^{\bullet}$ can be generated. The schema also shows the most commonly used inhibitors of the respiratory chain, which when acting downstream of the loci of production of $\mathrm{O}_{2}^{-}{ }^{-}$ would increase, while those acting upstream will inhibit $\mathrm{O}_{2}^{-} \cdot$ production.

\subsection{Secondary free radicals and other reactive species}

Once generated, these three main free radicals $\left(\mathrm{OH}^{\bullet}, \mathrm{O}_{2}^{-}{ }^{-}\right.$and $\left.\mathrm{NO}^{\circ}\right)$ can undergo an enormous variety of reactions with other molecules giving rise to new radicals or to species, which are oxidized or reduced. When new radicals are formed they are capable of undergoing further reactions originating chain reactions until one of the radicals reacts with a molecule (scavenger) to generate an unreactive compound. This widespread reactivity is the basis for the toxic effects of free radicals. For example, in their reactions with membrane lipids, $\mathrm{OH}^{\bullet}$ abstract an atom of hydrogen from polyunsaturated fatty acids forming $\mathrm{H}_{2} \mathrm{O}$ plus a modified fatty acid which is a carbon radical species readily reacting with molecular $\mathrm{O}_{2}$. The incorporation of $\mathrm{O}_{2}$ by the fatty acid carbon radical species transforms it into a peroxyl radical $(\mathrm{R}-\mathrm{COO}-\mathrm{COOH})$ which in turn is capable of abstracting another hydrogen atom from a nearby polyunsaturated fatty acid, thereby spreading out the alteration of lipids; alterna- tively, it might attack another double bond in the same molecule to form a cyclic endoperoxide compound which finally would break to generate malonaldehyde and other byproducts whose levels are usually determined to establish the magnitude of lipid peroxidation in circumstances of interest. The final point is that the modifications and breakdown of the lipids of the membranes change their fluidity and many of their basic properties. Aditionally, peroxyl radicals, malonaldehyde and other aldehyde byproducts of lipid peroxidation, as well as $\mathrm{OH}^{\bullet}$ itself and carbon centered radicals, can react with thiol and with amino groups of proteins or to attack many sites in essentially every amino acid to generate all kinds of distorted molecules (breakdown, intermolecular or intramolecular cross-linking of proteins with the formation of aggregates of membrane proteins, etc.) which ultimately imply the loss of the membrane function and its eventual destruction. The same kind of cross-linking, breakdowns and additional modifications can be made by $\mathrm{OH}^{\bullet}$ in DNA molecules and between DNA and nuclear proteins leading to alterations in the repair of DNA or in 
its replication or transcription. In sum, $\mathrm{OH}^{\bullet}$ is so reactive that it will react in the very same place where it is produced and disappear immediately as such entity, but at the same time new reactive molecules would appear which would spread the effects. The question in the context of the present article is if there exists any mechanism in the cells capable of circumscribing the action of $\mathrm{OH}^{\bullet}$ for it to act as the signaling molecule during hypoxia as Kietzmann et al. (2000) suggest. Whatever the mechanism(s) it should be based in two premises: first, the production of $\mathrm{OH}^{\bullet}$ should be located in a very restricted area of the cell; this restricted area must be coincident with the location of the cell machinery that initiates the hypoxic transduction cascade (for example, the $\mathrm{O}_{2}$-sensitive $\mathrm{K}^{+}$ channels or hypoxia inducible factor $1 \alpha, \mathrm{HIF}-1 \alpha$ ), and second, the ' $\mathrm{OH}^{\circ}$-receptor molecule' itself (e.g. the $\mathrm{O}_{2}$-sensitive $\mathrm{K}^{+}$channels or $\mathrm{HIF}-1 \alpha$ ) should act as a very effective $\mathrm{OH}^{\bullet}$ scavenger to avoid the widespread action of secondary reactive molecules with the inevitable loss of capacity to focus the hypoxic signal.

The $\mathrm{O}_{2}^{-}$is considerably much less reactive than $\mathrm{OH}^{\circ}$. It can be protonized to form $\mathrm{HO}_{2}{ }^{\circ}$ (hydroperoxyl radical) which has a greater reducing activity and which in addition is freely permeable to membranes owing to is lack of charge; both characteristics make $\mathrm{HO}_{2}{ }^{-}$an important free radical in spite of the fact that its concentration in biological systems is $1 / 100-400$ that of $\mathrm{O}_{2}^{-} \cdot$. In addition, hydroperoxyl radical is involved in the spontaneous dismutation of $\mathrm{O}_{2}^{-}$to $\mathrm{H}_{2} \mathrm{O}_{2}$ and molecular $\mathrm{O}_{2}$. This reaction, which involves the reduction of one $\mathrm{O}_{2}^{-}$and the oxidation of another to molecular $\mathrm{O}_{2}$, occurs through the formation of hydroperoxyl radical according to the equations:

$$
\begin{aligned}
& \mathrm{H}^{-}+\mathrm{O}_{2}^{-} \cdot \rightarrow \mathrm{HO}_{2}^{\bullet} \\
& \mathrm{HO}_{2}^{\bullet}+\mathrm{O}_{2}^{-}+\mathrm{H}^{+} \rightarrow \mathrm{H}_{2} \mathrm{O}_{2}+\mathrm{O}_{2}
\end{aligned}
$$

Superoxide radical can donate one electron to transition metals transforming $\mathrm{Fe}^{3+}, \mathrm{Cu}^{2+}$ and $\mathrm{Mn}^{3+}$ into $\mathrm{Fe}^{2+}, \mathrm{Cu}^{+}$and $\mathrm{Mn}^{2+}$, respectively, and then it acts as a reducing agent, but it can also act as an oxidizing agent reversing the reaction. These reducing/oxidizing reactions are very important because the enzymes responsible for the cellular elimination of $\mathrm{O}_{2}^{-}$, the superoxide dismutases (cytosolic or $\mathrm{CuZn}$ superoxide dismutase and mitochondrial or manganese superoxide dismutase), are metalloproteins containing those metals and through cycles of reduction and oxidation of their metals accelerate enormously the disappearance of $\mathrm{O}_{2}^{-}$. Other important reactions of $\mathrm{O}_{2}^{-}$include oxidation of ascorbate and the catechol ring to form ascorbate and diphenol radicals and $\mathrm{H}_{2} \mathrm{O}_{2}$. Another reaction of interest is that of $\mathrm{O}_{2}^{-}$with hypoclorous acid (formed in turn by the action of myeloperoxidase on $\mathrm{H}_{2} \mathrm{O}_{2}+$ $\mathrm{Cl}^{-} \rightarrow \mathrm{HOCl}+\mathrm{OH}^{-}$) to yield $\mathrm{O}_{2}, \mathrm{Cl}^{-}$and $\mathrm{OH}^{\bullet}$. Summarizing, we can state that up to this point most of $\mathrm{O}_{2}^{-}$ends up as $\mathrm{H}_{2} \mathrm{O}_{2}$ due to spontaneous and enzyme catalized dismutation. To some extent, we may say that $\mathrm{H}_{2} \mathrm{O}_{2}$ is the final common path of most free radicals in the organism.

However, $\mathrm{H}_{2} \mathrm{O}_{2}$ is harmful to the cells. It belongs to a category of molecules collectively called reactive oxygen species (ROS), which include free radicals. $\mathrm{H}_{2} \mathrm{O}_{2}$ and other ROS such as hypoclorous acid or peroxynitrite $\left(\mathrm{NO}^{\bullet}+\mathrm{O}_{2}^{-} \rightarrow \mathrm{ONOO}^{-}\right.$; see below) have in common with free radicals being more reactive than molecular $\mathrm{O}_{2}$, but unlike free radicals they do not have unpaired electrons. The toxicity of $\mathrm{H}_{2} \mathrm{O}_{2}$ would explain the existence of specific enzymatic systems to destroy it, including catalases $\left(2 \mathrm{H}_{2} \mathrm{O}_{2} \rightarrow 2 \mathrm{H}_{2} \mathrm{O}+\mathrm{O}_{2}\right)$ and peroxidases, the most important of which is glutathione peroxidase $\quad\left(\mathrm{H}_{2} \mathrm{O}_{2}+2 \mathrm{GSH} \rightarrow \mathrm{GSSG}+2 \mathrm{H}_{2} \mathrm{O}\right.$; GSSG is back reduced to GSH by the action of the NADPH based glutathione reductase). The toxicity of $\mathrm{H}_{2} \mathrm{O}_{2}$ is not exerted directly unless it is applied at high concentrations $(>10 \mu \mathrm{m}$ for many cells), but by the $\mathrm{OH}^{\bullet}$ it can generate upon reaction with transition metals by the Fenton reaction $\left(\mathrm{Fe}^{2+}+\mathrm{H}_{2} \mathrm{O}_{2} \rightarrow \rightarrow \rightarrow \rightarrow \mathrm{Fe}^{3+}+\right.$ $\mathrm{OH}^{\bullet}+\mathrm{OH}^{-}$) or upon homolytic fission by the action of ultraviolet light. We already have examined the widespread damaging effects of $\mathrm{OH}^{\bullet}$ (Fig. 3).

Nitric oxide $\left(\mathrm{NO}^{\bullet}\right)$ is also readily reactive with many other radicals. For example, it can react rapidly with superoxide to yield peroxynitrite $\left(\mathrm{NO}^{\bullet}+\mathrm{O}_{2}^{-} \rightarrow \mathrm{ONOO}^{-}\right)$and with hydroxyl radical to form nitrous acid $\left(\mathrm{NO}^{\bullet}+\mathrm{OH}^{\bullet} \rightarrow \mathrm{HNO}_{2}\right)$. 




Fig. 3. General schema of ROS generation in the organisms. $\mathrm{H}_{2} \mathrm{O}_{2}$, at the center of the scheme, represents a common final product whose levels are kept low by specific degrading enzymatic systems.

Peroxynitrites and nitrous acid are nitrogen reactive species capable of reacting with $\mathrm{SH}$ groups of proteins and with iron/sulfur electron transporting proteins of mitochondria. As we have already mentioned, $\mathrm{NO}^{\circ}$ can react in a reversible manner with cytochrome oxidase, thereby competing with $\mathrm{O}_{2}$; this might be a mechanism to control the oxidation rate of the energy-yielding compounds (nutrients). However, mitochondria must harmonize this potentially reversible regulating mechanism of $\mathrm{NO}^{\bullet}$ with its ability to react with $\mathrm{O}_{2}^{-}$to form peroxynitrite and through it to produce irreversible damaging effects on electron transporting proteins. Peroxynitrite can interact with tyrosine residues in a reaction catalyzed by superoxide dismutase to form the very stable 3-nitrotyroxine, changing the overall charge of the residues of tyrosine present in proteins and making it difficult for 3-nitrotyrosine containing proteins to assemble into multimeric units or to interact with other proteins (Beckman and Koppenol, 1996) and to participate in signaling cascades, by altering the efficiency of tyrosine phosphorylation. The great stability of 3-nitrotyrosine makes the measurement of its level a good index of nitric oxide/ peroxynitrite in biological systems. Peroxynitrite and other nitrogen reactive species can react with thiols, including that in glutathione, to form nitrosothiols. Special interest has recently been given to the nitrosylation of one cysteine residue in the ryanodine receptor/channel, which seems to occur in a $\mathrm{P}_{\mathrm{O}_{2}}$-dependent manner (Eu et al., 2000). When sarcoplasmic vesicles are exposed to ambient $\mathrm{P}_{\mathrm{O}_{2}}(\approx 150 \mathrm{mmHg})$ six to eight thiol residues per ryanodine receptor become oxidized, the oxidation reverting upon exposure to $\mathrm{P}_{\mathrm{O}_{2}}$ of $10 \mathrm{mmHg}$, which is in the range of that physiologically encountered in the muscle; on switching back to ambient $\mathrm{P}_{\mathrm{O}_{2}}$, reoxidation of those thiol residues takes place. These cysteine residues will constitute, according to ( $\mathrm{Eu}$ et al., 2000), an $\mathrm{O}_{2}$ sensor. It is conceptually important to realize that this potential $\mathrm{O}_{2}$-sensor needs to be coupled to a redox system, which must be present in the sarcoplasmic reticulum vesicles, and which must be responsible for switching back and forth from the oxidized to the reduced state. Only the reduced form of the channel is susceptible for physiological modulation by $\mathrm{NO}^{\circ}$, which does so by nitrosylating one of the reduced cysteine residues, or in other words, the redox state of the channel set by $\mathrm{P}_{\mathrm{O}_{2}}$ determines the capacity to respond to (or the ability to be regulated by) $\mathrm{NO}^{\bullet}$. 


\section{ROS as mediators of the hypoxic transduction cascade}

\subsection{Criteria to consider ROS mediators of a physiological cellular response}

Following classical studies on messengers such as neurotransmitters (McLennan, 1963) and the most recent article by Lander (1997) on ROS in signal transduction, it is possible to put forward a set of criteria as requirements to consider ROS as true second messengers with the capacity to control cellular functions under physiological conditions. A first criterion should be that the putative ROS molecule acting as messenger or mediator of the hypoxic response must increase or decrease during hypoxia; a given relationship (modulation can modify that putative relationship) should exist between the ROS level change, the intensity of hypoxia and the strength of the hypoxic response. The second criterion would be that the cellular mechanism responsible for the change in the level of ROS molecule, putative messenger, needs to be identified. The third criterion would be the definition of the primary target of the ROS as well as the definition of the change produced by the ROS molecule on its target. The possibility exists that the primary target of the putative messenger ROS molecule is itself the effector(s) of the cell response or on the contrary, it is possible that the primary target of ROS is a first link of a chain or cascade of events coupling the change in the ROS levels to the effector(s) of the cell response; in this latter case the entire cascade should be defined. The fourth criterion would be to define the cellular responses elicited by the effector(s). The fifth criterion would be the definition of mechanisms responsible for the inactivation of ROS signal. Obviously if the ROS species increase during hypoxia we should be looking for ROS degrading mechanisms, but if they decrease we should be looking for the enzyme or cells process leading to the restoration of normal ROS levels. In any case, if a given stimulus acts via a change in ROS levels, the mechanisms for the elimination of those ROS should be induced by prolonged presentation of the stimulus. The sixth criterion (pharmacological) would be that the manipulation of the ROS levels, whether by reagents that modulate glutathione levels or that directly scavenge ROS, should alter the cell response in a predictable and reproducible manner; a sixth $b$ or seventh criterion would be that overexpression or silencing of the expression of the ROS scavenging enzymes should alter the cell response in a predictable and reproducible manner.

\subsubsection{First criterion: the signal ROS levels during hypoxia}

The very first question that should be addressed is if hypoxia increases or decreases ROS in general or if there is a unique ROS species whose production follows a particular behavior during hypoxia. The classical view is that the rate of production of ROS changes in direct relation to the tissue $\mathrm{P}_{\mathrm{O}_{2}}$ (Chance et al., 1979; Archer et al., 1986, 1989). In fact, this view is generally accepted at present (Archer et al., 1993; Gorlach et al., 1994; Fandrey et al., 1994, 1997; Halliwell and Gutteridge, 1999; Kietzmann et al., 2000; Gnaiger et al., 2000). However, quite recently Schumacker and coworkers (Chandel et al., 1998; Duranteau et al., 1998; Chandel and Schumacker, 2000; Chandel et al., 2000) have found the opposite: hypoxia produces an increase in the cellular rate of ROS production which takes place at the level of mitochondria and which is proportional to the level of hypoxia. Chandel et al. (1998) claim that their measurements using dichlorofluorescein fluorescence, which apparently measures preferentially $\mathrm{H}_{2} \mathrm{O}_{2}$, are the correct ones. However there are many measurements using different methods (see Chance et al., 1979) in which it has been shown that hypoxia decreases the rate of production of ROS, the decrease being attributed to a decrease of production in mitochondria as well as in microsomal and peroxisomal enzymes. Archer et al. (1993) and Paky et al. (1993) using lucigenin chemiluminescence, which apparently measures preferentially $\mathrm{O}_{2}^{-}$(Halliwell and Gutteridge, 1999), also found that hypoxia decreases ROS production rate. Similarly contradictory are the observations regarding to $\mathrm{CoCl}_{2}$ (an inducer of EPO production), which decreases the production of ROS if they are measured with dihydrorhodamine 123 (Fandrey et al., 1997), or increases 
their production if ROS are measured with dichlorofluorescein (Chandel et al., 1998). Interestingly, both dyes yielded an inhibition of ROS generation under rotenone and diphenileneiodonium (DPI) (Cross et al., 1990; Ehleben et al., 1997; Chandel et al., 1998; Duranteau et al., 1998); rotenone and DPI also decreased lucigenin chemiluminescence (Archer et al., 1993, 1999). However, while antimycin A increased dichlorofluorescein fluorescence (Chandel et al., 1998) it decreased lucigenin chemiluminescence (Archer et al., 1993).

With this panorama it is difficult to make a meaningful formulation of the putative ROS molecule(s), which are signals for the hypoxic transduction cascade. We do not know if the signal should be a particular ROS species that decreases during hypoxia, a general decrease in the ROS levels, or if on the contrary, we should be searching for something that increases during hypoxia. We would like to quote (Semenza, 1999, 2000) when he writes that 'the direct measurements of ROS are so demanding that they generate data supporting opposing views'. However, we want to make explicit some thoughts on the problem, being aware that experimental data might contradict the opinions expressed here. When we consider the general mechanisms for ROS production presented in previous paragraphs, the intuitive notion would be that the rate of production of ROS in cells should be directly proportional to the $\mathrm{P}_{\mathrm{O}_{2}}$ of the cells. Reactions of auto-oxidation as well as oxidations driven by enzymes and the acceptance by molecular $\mathrm{O}_{2}$ of electrons leaking at the level of the quinone pool in mitochondria (see Fig. 2) would decrease during hypoxia, when $\mathrm{P}_{\mathrm{O}_{2}}$ is diminished. At the same time, however, it would appear that the generation of $\mathrm{O}_{2}^{-} \cdot$ at the quinone pool level would depend on the rate of flow of electrons through the respiratory chain, i.e. on the respiratory rate. As stated in the first section of this article, cell systems involved in the general homeostasis of $\mathrm{O}_{2}$ are activated by hypoxia, this activation requiring an increase in cell respiration to support cell and homeostatic loop function (Obeso et al., 1993, 1997). Thus, it could be expected that in these specialized cells hypoxia produces an increase in electron flow during an ample range of hypoxia (from $\approx 70$ to $20 \mathrm{mmHg}$ of arterial $\mathrm{P}_{\mathrm{O}_{2}}$ ), and thereby, an increase in the electron leakage and mitochondrial formation of $\mathrm{O}_{2}^{-}$is conceivable in those situations (see Fig. 3 in Hoshi and Heinemann, 2001) when hypoxia is intense enough a compromise will occur and in spite of the high affinity of cytochrome oxidase for $\mathrm{O}_{2}$, it will be unable to transfer enough electrons to $\mathrm{O}_{2}$ and the respiratory rate and the genesis of ATP will drop. In the case of the CB in vivo this metabolic compromise occurs at arterial $\mathrm{P}_{\mathrm{O}_{2}} \approx 20 \mathrm{mmHg}$; below this $\mathrm{P}_{\mathrm{O}_{2}}$ the $\mathrm{CB}$ is unable to adequately signal the level of hypoxia and chemoreceptor action potential frequency decreases, instead of increasing (see Fidone and Gonzalez, 1996). The majority of the cells of the organism will behave during hypoxia as the $\mathrm{CB}$ below the compromise $\mathrm{P}_{\mathrm{O}_{2}}$ : all $\mathrm{O}_{2}^{-}$-generating processes including that of mitochondria would decrease as the intensity of hypoxia increases. To state this in a different manner, it would appear that a differential response could be expected: in most cells of the organism hypoxia would tend to decrease ROS production while in CB chemoreceptor cells, in EPO-producing cells and in smooth muscle cells of the pulmonary arteries hypoxia would tend to increase ROS production at least in those ranges of hypoxia compatible with life. In contrast, Schumacker and co-workers measured an increase in ROS production in cardiomyocytes and hepatoma cells (EPO-producing) which is comparable in magnitude and in $\mathrm{P}_{\mathrm{O}_{2}}$ dependence in both cell types (Chandel et al., 1998; Duranteau et al., 1998) and Fandrey et al. (1994) measured a decrease in the rate of production and release of $\mathrm{H}_{2} \mathrm{O}_{2}$ to the incubating solution by EPO-producing hepatoma cells precisely in the range of $\mathrm{P}_{\mathrm{O}_{2}}$ where they secrete EPO.

In sum, the first criterion is not settled, we do not know whether hypoxia increases or decreases ROS levels.

\subsubsection{Second criterion: cell mechanisms} responsible for the change in ROS production during hypoxia should be defined

Those proposing that hypoxia would decrease ROS levels (Cross et al., 1990; Youngson et al., 1993; Acker, 1994a,b; Acker and Xue, 1995; Fan- 
drey et al., 1994; Kietzmann et al., 2000; Weir and Archer 1995; Archer et al., 1993, 2000; Fu et al., 2000) have been considering that a NADPH oxidase similar or identical to that present in phagocyte cells would be responsible for that decrease. The main findings to propose NADPH oxidase as the mechanism for the decrease in ROS production during hypoxia were: (1) the microspectrophotometric description in the $\mathrm{CB}$ of a cytochrome bgss, (2) the microspectrophotometric observation that hypoxic activation of the $\mathrm{CB}$ was paralleled by a reduction of FAD and NADP ${ }^{+}$ and (3) the observation that DPI (an inhibitor of NADPH oxidase, and in general of all flovoenzymes) was able to activate the $\mathrm{CB}$ chemoreceptors' sensory discharge and to occlude the response to hypoxia. At the same time, DPI completely eliminated the fluorescent signal emitted by rhodamine 123 attributed to $\mathrm{H}_{2} \mathrm{O}_{2}$ (Cross et al., 1990). These initial observations were soon followed by the immunocytochemical demonstration of all the subunits of NADPH oxidase in the CB (Kummer and Acker, 1995), although more recent studies have shown that most of the intraglomic immunostaining is localized in macrophages infiltrating the $\mathrm{CB}$ tissue (Dvorakova et al., 2000).

As discussed elsewhere (Gonzalez, 1998), this oxidase has a $\mathrm{Km}$ for $\mathrm{O}_{2}(5-30 \mu \mathrm{m}$ or 3-18 $\mathrm{mmHg}$ ) that would make reasonable the proposition that at the arterial $\mathrm{P}_{\mathrm{O}_{2}}$ threshold for the activation of the homeostatic loops the rate of $\mathrm{O}_{2}^{-}$ formation by NADPH oxidase could start falling below Vmax. There are, however, several observations and considerations that in our opinion make untenable the proposal that the decrease in the activity of NADPH oxidase, and thereby the decrease in ROS generated by it, are the mediators or messengers linking the decrease of $\mathrm{P}_{\mathrm{O}_{2}}$ to the cellular effectors. For example, NÁDPH is a multimeric enzyme with two membrane-bound and several cytoplasmic subunits, and to become active they need to be assembled in the membrane (Dang et al., 2001). The question therefore arises: what is the mechanism promoting the assembling of the subunits and of keeping the enzyme permanently active in resting normoxic conditions? Also, does the proposed hypoxic inhi- bition imply disassembling of the enzyme? Taking into account that $\mathrm{K}^{+}$channels are early effectors (may be the first effectors) of the hypoxic transduction cascade in chemoreceptor cells and in PASMC, and that they respond to low $\mathrm{P}_{\mathrm{O}_{2}}$ in isolated membrane patches of rabbit and rat chemoreceptor cells (Ganfornina and LópezBarneo, 1991; Riesco et al., 2001), how can we explain any activity and any back and forth change in activity of the enzyme in the inside-out patches perfused with saline at different $\mathrm{P}_{\mathrm{O}_{2}}$ ? In addition, NADPH oxidase does not react with CO (Gabig et al., 1982; Iizuka et al., 1985) and yet $\mathrm{CO}$, at concentrations just enough to compensate the decrease in $\mathrm{P}_{\mathrm{O}_{2}}$, is capable of preventing the inhibition of the $\mathrm{K}^{+}$channels produced by hypoxia (López-López and Gonzalez, 1992), the hypoxic activation of chemoreceptor activity (Lahiri et al., 1993) and the hypoxic vasoconstriction of the lung circulation (Tamayo et al., 1997), implying that the cell system where $\mathrm{O}_{2}$ is sensed has an affinity for $\mathrm{CO}$ comparable to that for $\mathrm{O}_{2}$ itself (Fig. 4).

Returning to the observations supporting NADPH oxidase involvement in $\mathrm{O}_{2}$ sensing, it should be mentioned that recent studies have shown that, as predicted by the hypothesis, DPI does activate chemoreceptor cells promoting release of catecholamines in intact rat and rabbit $\mathrm{CB}$; however, it does not occlude the response to hypoxia in either species (Obeso et al., 1999, 2000a). In the same studies, two additional inhibitors of the oxidase did not modify the release of catecholamines in normoxic or in hypoxic conditions suggesting that DPI activation of chemoreceptor cells was not related to its ability to inhibit NADPH oxidase. In this regard, it should be mentioned that the effect of DPI on sensory discharges at concentrations capable of fully inhibiting the oxidase (Cross et al., 1990; see above) was much smaller than the response to a moderately intense hypoxic stimulus and, in addition, DPI produced irreversible damage to the CB-carotid sinus nerve preparation suggesting that the action of DPI was not related to the action of hypoxia. Even more recently, it has been shown that chemoreceptor cells from mice null for the neutrophil NADPH oxidase (for the $91 \mathrm{kDa}$ 



Fig. 4. Effects of CO on responses elicited by hypoxia. In (A) (redrawn with data from López-López and Gonzalez, 1992) it can be seen that the inhibition of the $\mathrm{K}^{+}$currents produced by hypoxia $\left(\mathrm{H}, 5 \% \mathrm{O}_{2}\right.$ equilibrated solutions vs. $\mathrm{C}$, 20\% $\mathrm{O}_{2}$ in control conditions) was reversed by $\approx 75 \%$ in the presence of $\mathrm{CO}\left(\mathrm{H}+\mathrm{CO} ; 5 \% \mathrm{O}_{2}+10 \% \mathrm{CO}\right.$ equilibrated solutions). In (B) the increase in the carotid sinus nerve activity elicited by hypoxia $\left(\mathrm{P}_{\mathrm{O}_{2}}=50\right.$ vs. 550 torr in control) was inhibited by about $70 \%$ by $\mathrm{CO}\left(\mathrm{O}_{2}=50\right.$ torr $+\mathrm{CO}=140$ torr) (calculated and drawn with data from Lahiri et al., 1993). In (C) the increase in pulmonary arterial pressure elicited by hypoxia (blood $\mathrm{P}_{\mathrm{O}_{2}} \approx 23$ vs. $140 \mathrm{mmHg}$ in control conditions) was reversed by nearly $90 \%$ in the presence of CO (blood $\mathrm{P}_{\mathrm{O}_{2}} \approx 23 \mathrm{mmHg}$ and $\mathrm{PCO} \approx 56 \mathrm{mmHg}$ ) (redrawn with data from Tamayo et al., 1997).

membrane bound subunit) exhibit a normal response to hypoxia measured as $\mathrm{Ca}^{2+}$ transients in chemoreceptor cells or as ventilatory response (Roy et al., 2000).

The situation in the pulmonary circulation is comparable. NADPH oxidase is present in PASMC and its inhibition with DPI fully blocked the hypoxic vasoconstriction (Thomas et al., 1991; Grimminger et al., 1995; Thompson et al., 1998) and decreased lucigenin chemoluminiscence (Archer et al., 1999). Contrary to the hypothesis that hypoxia inhibits NADPH oxidase (see Weir and Archer, 1995), these findings are compatible with the opposite notion, i.e. NADPH oxidase, if involved at all on hypoxic vasoconstriction, should be activated by hypoxia (and not inhibited) so that its inhibition by DPI abolishes the vasoconstrictor response. Consistent with this idea, Marshall et al. (1996) observed that hypoxia does indeed increase the activity of NADPH oxidase. However, NADPH oxidase does not appear to be involved at all on the genesis of hypoxic pulmonary vasoconstriction, because knock out animals for the neutrophil oxidase exhibited a normal hypoxic pulmonary vasoconstriction (Archer et al., 1999, 2000). Even further, the data of Archer et al. (1993, 1999, 2000) appear to exclude ROS as mediators of the hypoxic pulmonary vasoconstriction. Thus, DPI and rotenone decreased lucigenin chemoluminiscence and, as just stated, DPI inhibits the hypoxic vasoconstriction, but rotenone per se produced a vasoconstrictor response, which was greater in null animals for NADPH oxidase. Both agents, DPI and rotenone, would inhibit complex I at mitochondrial level and reduce ROS production, and rotenone produces pulmonary vasoconstriction while DPI suppresses it. To further complicate the interpretations it has been found that in isolated PASMC DPI per se increased $\mathrm{Ca}_{\mathrm{i}}^{2+}$ and elicited a contractile response in an ample range of concentrations, and in myocytes contracted by hypoxia DPI at $1-5 \mu \mathrm{m}$ inhibited the contraction but did not reduce the $\mathrm{Ca}_{\mathrm{i}}^{2+}$ (Zhang et al., 1997), indicating that DPI has side-effects down in the transduction cascade probably unrelated to NADPH oxidase inhibition (as appears to be the case in the $\mathrm{CB}$, see above). Previously, it had been shown that DPI per se inhibited $\mathrm{K}^{+}$and $\mathrm{Ca}^{2+}$ currents in a non-specific manner in PASMC (Weir et al., 1994) and carotid body chemoreceptor cells (Wyatt et al., 1994).

Regarding EPO-producing cells (Gorlach et al., 1993; see Acker, 1994b) found microspectrophotometrical evidence of the presence of NADPH oxidase in hepatoma EPO-producing cells, and in western blot analysis they showed the presence in those cells of two of the subunits of the enzyme. Their proposal was identical to that described above for the $\mathrm{CB}$ chemoreceptor cells: hypoxia 
would decrease the activity of the enzyme and ROS levels would decrease, this decrease being a critical link between low $\mathrm{P}_{\mathrm{O}_{2}}$ and the transcription of the EPO gene. However, Gleadle et al. (1995) showed that DPI per se applied in a range of concentrations from 0.3 to $5 \mu \mathrm{M}$ did not activate EPO production in normoxic hepatoma cells; on the contrary, DPI inhibited in a dose-dependent manner hypoxia-induced, but not $\mathrm{CoCl}_{2}$-induced, EPO transcription. Obviously these findings argue against a role of NADPH oxidase inhibition in the genesis of the hypoxic response, otherwise DPI in normoxic conditions should mimic hypoxia and in hypoxic conditions should be ineffective or potentiate the effect of hypoxia. Regarding the lack of effect of DPI on $\mathrm{CoCl}_{2}$-induced EPO transcription the interpretation is difficult because as already stated $\mathrm{CoCb}$ decreases ROS production according to Fandrey et al. (1997) and increases the production according to Chandel et al. (1998). The latter authors found that the production of ROS induced by $\mathrm{CoCl}_{2}$ is of unknown, but extramitochondrial origin, and in any case insensitive to DPI. Finally, the participation of NADPH was questioned by Ratcliffe et al. (1995) arguing that EPO deficiency was not a trait in granulomatous patients which lack one or other subunit of NADPH oxidase and therefore the functional enzyme, and in fact, it was demonstrated by Wenger et al. (1996) that B-cell lines derived from normal and from granulomatous patients expressed vascular endothelial growth factor under hypoxic conditions and under $\mathrm{CoCl}_{2}$ treatment in a very similar manner (the upregulation of vascular endothelial growth factor and EPO genes expression is considered to be under similar control); even further, reconstitution of the NADPH oxidase activity in granulomatous cells by transfecting the absent genes did not alter the sensitivity to hypoxia suggesting that $\mathrm{H}_{2} \mathrm{O}_{2}$ levels are not critical to control the HIF- $1 \alpha$-dependent expression of vascular endothelial growth factor.

However, in keeping with the NADPH model, Fandrey et al. (1997) reported that desferrioxamine (an iron chelator which also increases EPO gene expression) and $\mathrm{CoCl}_{2}$ decreased the production of ROS (as determined by dihydrorhodamine 123 fluorescence) as hypoxia does, therefore, they proposed that this diminution of ROS was the common factor for the three situations to increase EPO production. Even further, Fandrey et al. (1994) have previously found that addition of $\mathrm{H}_{2} \mathrm{O}_{2}$ to the incubation medium (at concentrations greater than $100 \mu \mathrm{M}$ ) reduced or abolished the production of EPO induced by hypoxia, and in the 1997 article (Fandrey et al., 1997) they reported that desferrioxamine antagonized the action of $\mathrm{H}_{2} \mathrm{O}_{2}$ concluding that $\mathrm{H}_{2} \mathrm{O}_{2}$ acted via $\mathrm{OH}^{\bullet}$ generated by a Fenton reaction. These and other observations are in the most recent formulation of the model linking NADPH oxidase and hypoxic activation of gene expression. In this model the inhibition of the oxidase in hypoxia leads to a decrease in $\mathrm{H}_{2} \mathrm{O}_{2}$ and as a consequence to a decrease in $\mathrm{OH}^{\circ}$ in perinuclear areas of the cell which ultimately would cause a change from oxidized to reduced state of the transcription factors triggering the transcription of hypoxia regulated genes (Kietzmann et al., 2000). As already stated, it is hard for us to imagine a localized production of $\mathrm{OH}^{\bullet}$. Overall, however, this notion of a diminished rate of ROS production during hypoxia would fit the observations of Huang et al. (1996) who showed that hypoxia inducible factor- $1 \alpha$ (HIF-1 $\alpha$; this factor would be the primary target or the primary effector of hypoxia in EPO-producing cells; see Fig. 1) which in normoxic conditions is degraded in the proteosome, is stabilized during hypoxia by a reduction process which allows it to reach the nucleus and to bind to the EPO gene enhancer to activate the rate of transcription. In fact Huang et al. (1996) reported that pre-exposure of hepatoma cells to $\mathrm{H}_{2} \mathrm{O}_{2}$ prevented hypoxia induced $\mathrm{HIF}-1 \alpha$ protein accumulation, and additionally several back and forth putative manipulations of the HIF-l $\alpha$ redox state with sulfhydryl reagents agreed with the overall notion that hypoxia stabilized HIF- $1 \alpha$ by facilitating its reduced form via a decrease in ROS production.

As a result of all these difficult data, the trend in 2000 was that NADPH oxidase was not related to $\mathrm{O}_{2}$-sensing. Critical pieces to this thinking were the experiments in granulomatous patients and the experiments with knock out animals described above. However, new players are to be included in this venue. In neuroepithelial bodies (airway 
Table 1

Lack of positive correlation between ROS levels and hypoxic responses

\begin{tabular}{lllll}
\hline & ROS levels & Carotid body & EPO-cells & Lung circulation \\
\hline Hypoxia & Decrease/increase & Stimulates & Stimulates & Vasoconstriction \\
Rotenone & Decrease & Stimulates & Inhibits hypoxic response & Vasoconstriction \\
DPI & Decrease & Stimulates & 0 in normoxia inhibits hypoxic response & Inhibits hypoxic response \\
Antimycin A & Increase/decrease & Stimulates & 0 in normoxia, 0 in hypoxia & Vasoconstriction \\
Cyanide (Azide) & Increase & Stimulates & 0 in normoxia, 0 in hypoxia & Vasoconstriction \\
\hline
\end{tabular}

chemoreceptors) whose cells possess $\mathrm{O}_{2}$-modulated $\mathrm{K}^{+}$channels and are positive to NADPH oxidase, DPI mimics hypoxia on $\mathrm{K}^{+}$currents (Youngson et al., 1993; Fu et al., 1999) and the response to hypoxia of the cells is lost in knock outs for NADPH oxidase (Fu et al., 2000). These finding would suggest that NADPH oxidase is linked to $\mathrm{O}_{2}$-sensing in these cells. Moreover, very recently several isoforms of NADPH oxidase have been cloned (e.g. Zhu et al., 1999; Geiszt et al., 2000) one of them named renox with a location in the renal cortex compatible with a possible function in the control of EPO-gene (Geiszt et al., 2000).

The proponents of the theory that ROS increase during hypoxia (Chandel et al., 1998, 2000; Duranteau et al., 1998; Chandel and Schumacker, 1999, 2000) state that it takes place at the level of mitochondria (Fig. 2). Superoxide itself or $\mathrm{H}_{2} \mathrm{O}_{2}$ (product of $\mathrm{O}_{2}^{-}$dismutation) would reach the cytosol to stabilize HIF-la by promoting its oxidized form (Chandel et al., 2000; just the opposite to the claim given by Huang et al., 1996; see above). We have already speculated that in cells involved in homeostatic loops we should probably expect an increase in the production of ROS due to increased flow of electrons in the respiratory chain. Schumacker and co-workers propose that the increase in ROS they found would be due to a certain degree to the reduced state of the entire respiratory chain produced by the inadequate functioning of cytochrome oxidase imposed by hypoxia; this extra reduced state of the entire respiratory chain (in comparison to normoxia) would favor the reduced state of quinones and the leakage of electrons to form $\mathrm{O}_{2}^{-} \cdot$. We would tend to believe that in cells involved in oxygen homeo- static loops this would occur at more extreme hypoxias due to the high affinity of cytochrome oxidase on the one hand (see Gnaiger et al., 2000) and due to the high blood flow of the organs wherein reside the cells forming part of the $\mathrm{O}_{2}$ homeostatic loops, on the other.

A different question is whether increased ROS levels could be unequivocally considered mediators of the hypoxic responses. The answer is no (Table 1). Thus, hypoxia, antimycin A and azide (and therefore cyanide) increase ROS levels (Duranteau et al., 1998) and only hypoxia increases the rate of transcription of EPO gene (Tan and Ratcliffe, 1991; Pugh et al., 1991; Firth et al., 1994). Rotenone and DPI, which decrease the levels of ROS, inhibit the hypoxic increase in EPO-gene transcription, but cyanide and antimycin A did not. In conjunction these data indicate that ROS levels per se are not related to EPO gene transcription, and that the energy metabolism of the cells is similarly unrelated to EPO gene transcription (during hypoxia, the three poisons, rotenone, cyanide and antimycin A should dramatically decrease ATP/ADP + $\mathrm{AMP}+\mathrm{Pi}$ quotients and only rotenone inhibits the hypoxic response). In the case of the $\mathrm{CB}$, all metabolic poisons including rotenone and amytal (acting at complex I), antimycin A (acting at complex III) and cyanide and azide (acting at complex IV; see Fig. 2) stimulate the CB chemoreception (Anichkov and Belen'kii, 1963; Joels and Neil, 1968; Mulligan and Lahiri, 1982; Matsumoto et al., 1987; Obeso et al., 1989a; Duchen and Biscoe, 1992), and yet, rotenone and amytal decrease ROS levels while the rest of the inhibitors increase them. In the pulmonary circulation, the situation is comparable: hypoxia, 
rotenone and antimycin $\mathrm{A}$ which decreased lucigenin chemiluminescence increased pulmonary artery pressure and cyanide which increased chemiluminescence also increased pulmonary arterial pressure (Archer et al., 1993); obviously, according to Chandel and coworkers only rotenone should produce a decrease in ROS the rest of the situations would increase them, and yet all experimental maneuvers increased pulmonary artery pressure.

\subsubsection{Third criterion. The primary target for the increased or decreased levels of ROS should be identified. The change produced in the target by the signal (change in ROS levels) should be defined. The mechanisms of target/effector coupling should also be defined}

We do not know the identity of the primary ROS targets in the hypoxic transduction cascade. Therefore, we will equate the primary target of ROS with the first known or suspected effector on the cells which are $\mathrm{K}^{+}$channels in the case of $\mathrm{CB}$ chemoreceptor and PASMC and HIF-1 $\alpha$ in the case of EPO-producing cells (see Fig. 1). The recognition that release of catecholamines induced by hypoxia in the $\mathrm{CB}$ chemoreceptor cells, as well as that induced by high extracellular $\mathrm{K}^{+}$, was inhibited by dihydropyridine antagonists of L-type $\mathrm{Ca}^{2+}$ channels (Obeso, 1984) suggested to us that hypoxia must depolarize chemoreceptor cells. This observation prompted us to develop a primary culture of rabbit $\mathrm{CB}$ dissociated cells to study electrophysiologically chemoreceptor cells. In agreement with previous data of our laboratory (Obeso, 1984; Almaraz et al., 1986; Rocher et al., 1988), using the patch clamp technique in the isolated preparation of rabbit chemoreceptor cells we demonstrated that these cells were excitable cells with $\mathrm{Na}^{+}, \mathrm{K}^{+}$and $\mathrm{Ca}^{2+}$ voltage-dependent channels, and more importantly, that a transient component of the outward directed $\mathrm{K}^{+}$current was reversibly inhibited by hypoxia (LópezBarneo et al., 1988; López-López et al., 1989); recent studies have identified the $\mathrm{K}^{+}$channel supporting this transient $\left(\mathrm{O}_{2}\right.$-sensitive current as a putative member of the Kv.4 family (Pérez-García et al., 2000). Following this initial finding, the presence of $\mathrm{O}_{2}$-modulated $\mathrm{K}^{+}$currents in chemoreceptor cells has been recognized in all the species studied. In the rat chemoreceptor cells two types of $\mathrm{O}_{2}$-modulated $\mathrm{K}^{+}$channels have been described; a $\mathrm{Ca}^{2+}$-dependent $\mathrm{K}^{+}$current (Peers, 1990) carried out by the maxi-K ${ }^{+}$(Wyatt and Peers, 1995; López-López et al., 1997) and a leak voltage-independent current (Buckler, 1997, 1999), recently identified as TASK-1 channel (Buckler et al., 2000). In the cat CB chemoreceptor cells, $\mathrm{K}^{+}$current sensitive to hypoxia is a delayed rectifier-like current (Chou and Shirahata 1996). In PASMC, the original description of Demodulated KT channels was made on freshly dispersed canine fibers, and it was found that the KT current sensitive to hypoxia was $\mathrm{Ca}^{2+}$-dependent (Post et al., 1992). Soon after, Yuan et al. (1993) found that in primary cultures of rat PASMC the current sensitive to hypoxia was of the $\mathrm{Ca}^{2+}$ independent delayed rectifier type (Yuan et al., 1993). In more recent studies (e.g. Yuan et al. 1998; Archer et al., 1998; Patel et al., 1997; Osipenko et al., 2000) several Kv channels have been identified in PASMC and it would appear that those channels most likely to carry the $\mathrm{O}_{2}$-sensitive current would be the homomeric $\mathrm{Kv1}$.2, Kv1.5, the Kv2.1, the Kv3.1 and the heteromeric Kv1.2/Kv1.5 and Kv2.1/Kv9.3 (see Pérez-García and López-López, 2000; Archer et al., 2000).

In accord with criterion 3, experimental findings must clarify to what extent, if any, the $\mathrm{O}_{2}$ modulated channels are sensitive to redox changes, and if so, to determine if those redox changes are likely to be produced by hypoxia. Fast inactivating channels supporting macroscopic currents like those sensitive to hypoxia in rabbit chemoreceptor cells are susceptible to modulation by redox agents including $\mathrm{H}_{2} \mathrm{O}_{2}$, dithiothreitol, dithiodipyridine, GSH and GSSG (Ruppersberg et al., 1991; Vega-Saenz de Miera and Rudy, 1992; López-Barneo et al., 1999; PérezGarcía et al., 1999), and in general, the modulation occurs in an adequate manner (taking as valid the assumption that hypoxia decreases ROS levels), i.e. reducing agents decrease the opening probability of the channels or the amplitude of the currents and oxidizing agents do the opposite. However, the opening probability of $\mathrm{O}_{2}$-sensitive 
$\mathrm{K}^{+}$channels decreases in isolated patches on lowering $\mathrm{P}_{\mathrm{O}_{2}}$ (Ganfornina and López-Barneo, 1991; Pérez-García et al., 1999) in a reversible manner, and to our knowledge, $\mathrm{O}_{2}$ at the ranges of pressures we are dealing with $(10-150 \mathrm{mmHg})$, cannot oxidize or reduce thiol or other functional groups in the proteins (except for some autoxidation of tyrosine and tryptophan; Halliwell and Gutteridge, 1999). In addition, it is necessary to postulate that a redox system capable of transferring the electrons back and forth to the channel protein is present in the isolated membrane patches (see the above comments on the article by $\mathrm{Eu}$ et al., 2000). Furthermore, $\mathrm{CO}$ is able to prevent or to reverse the action of hypoxia on $\mathrm{K}^{+}$ currents (i.e. $\mathrm{CO}$ behaves as $\mathrm{O}_{2}$; López-López and Gonzalez, 1992) and yet there are no cell mechanisms by which the highly unreactive $\mathrm{CO}$ at the concentrations used can substitute $\mathrm{O}_{2}$ to increase the rate of ROS production. Maxi-K ${ }^{+}$channels, which are $\mathrm{O}_{2}$-modulated in rat chemoreceptor cells, are also sensitive to modulation by redox reagents like those mentioned above for the transient $\mathrm{K}^{+}$channels, but the direction of those modulations are not always the expected ones (Thuringer and Findlay, 1997; Liu et al., 1999; Soh et al., 2001; Riesco et al., 2001; but see Tang et al., 2001). Therefore, the notion of hypoxia acting through reduction of sulfhydryl or other chemical groups of the channel proteins susceptible to redox modulation seems untenable, especially if we consider that $\mathrm{CO}$ is able to reverse the effect of hypoxia in isolated membrane patches of rat chemoreceptor cells increasing the opening probability of maxi- $\mathrm{K}^{+}$when it is decreased by hypoxia (Riesco et al., 2001). In this regard, it should be mentioned that in a recent study from our laboratory it was possible to clearly distinguish between the action of reducing agents and the action of low $\mathrm{P}_{\mathrm{O}_{2}}$ : we observed that dithiothreitol was able to modify some kinetic properties of transfected shaker and shaker/ $\beta 1.2$ and Kv4.2/ $\beta 1.2$ channels, while low $\mathrm{P}_{\mathrm{O}_{2}}$ only modulated the latter channels (Pérez-García et al., 1999). In other words, it is possible that reducing agents alter the conducting properties of ion channels, but that does not necessarily mean that hypoxia alters those properties, and if hypoxia alters them, it may be that the direction of the alteration could be different. The same type of arguments can be made regarding the regulation of $\mathrm{K}^{+}$channels by redox agents versus hypoxic regulation in PASMC: in general the modification of the currents by reducing agents corresponds to that of hypoxia (see Archer et al., 2000) but the sensitivity to hypoxia of Kv3.1 in isolated patches (Osipenko et al., 2000) ${ }^{1}$ brings the same considerations just mentioned in the case of the $\mathrm{CB}$ chemoreceptor cells.

The identification of HIF-1 $\alpha$ as the primary effector in EPO producing cells occurred as a result of coordinated studies of several groups. Transgenic mice carrying a $4 \mathrm{~kb}$ fragment of the human erythropoietin gene which contained the 5 exons and 4 introns of the intact gene, a $0.4 \mathrm{~kb}$ of the $5^{\prime}$ end and a $0.7 \mathrm{~kb}$ of the $3^{\prime}$ end exhibited hypoxic induction of the human gene as bleeding resulted in increased levels of human EPO mRNA in the liver of the mice; in addition, several transgenic mice derived from different independent cell lines were polycythemic (see Semenza 1994). The findings indicated that the EPO-gene fragment contained hypoxia regulated elements. The description by Golberg and co-workers of two human hepatoma cell lines exhibiting hypoxia regulated expression of EPO (Goldberg et al., 1987, 1988) allowed an ample series of trasfection experiments with reporter genes which fed to the discovery of the 3' enhancer region with the ability to bind proteins (e.g. Pugh et al., 1991). A search aimed at identifying the protein factors binding to the $3^{\prime}$ enhancer culminated with the

\footnotetext{
${ }^{1}$ In our whole-cell patch recordings, $\mathrm{CO}$ was used by gas bubbling of the perfusing solutions. The gas mixtures contained: $20 \% \mathrm{O}_{2} / 80 \% \mathrm{~N}_{2}$, in control conditions; $5 \% \mathrm{O}_{2} / 95 \% \mathrm{~N}_{2}$, in hypoxic conditions, and; $5 \% \mathrm{O}_{2} / 10 \% \mathrm{CO} / 85 \% \mathrm{~N}_{2}$, during $\mathrm{CO}$ application. This concentration of $\mathrm{CO}$ prevented or reversed the effect of $5 \% \mathrm{O}_{2}$ by $\approx 70 \%$. With this $\mathrm{O}_{2} / \mathrm{CO}$ ratio, cytochrome oxidase should not be inhibited and therefore ROS production of mitochondrial origin would not increase; it is possible that some other enzymatic system with the potential to generate ROS (e.g. cytochrome P450 oxidases) could be inhibited, and therefore, it is possible that ROS could have decreased (Coburn R.F. and Forman H. J. Carbon monoxide toxicity. In A.P. Fishman, ed. The Respiratory System IV. American Physiological Society, Bethesda, MD, pp 439-56, 1987).
} 
identification of HIF-1 (Wang and Semenza, 1993a,b) as a factor induced by hypoxia, capable of binding to the 3' enhancer region of EPO and other hypoxia-regulated genes and capable of causing an increase in their rate of transcription. Thereafter, it was demonstrated that in fact HIF1 was a heterodimer composed of HIF-1 $\alpha$, whose levels are regulated by low $\mathrm{P}_{\mathrm{O}_{2}}$, and by the constitutively expressed HIF-1 $\beta$ [also known as ARNT (aryl hydrocarbon receptor nuclear translocator), as AhR (aryl hydrocarbon receptor) and as dioxin receptor], the dimerization was shown to be necessary, not for the translocation of both components to the nucleus, but for the stable association of HIF-1 within the nuclear compartment (see Gassmann et al., 2000). Additional studies demonstrated that HIF-1 $\alpha$ as well as HIF-1 $\beta$ mRNA levels, transcription and translation rates were not modified by hypoxia. Since HIF-1 $\alpha$ protein increased during hypoxia it implied that in normoxia the protein is degraded and that hypoxia prevents the degradation (Huang et al., 1996).

Therefore, the question we should make at this point is how the change in ROS levels produces such stabilization of HIF- $1 \alpha$ to prevent its degradation. Huang et al. (1996) showed that the levels of HIF-1 $\alpha$, which are increased by hypoxia, decreased soon if intact cells were re-exposed to normoxia $\left(21 \% \mathrm{O}_{2}\right)$, but exposure of cell extracts to the same normoxic levels of $\mathrm{O}_{2}$ did not alter the binding of HIF- $1 \alpha$ to DNA. In other words, for high $\mathrm{P}_{\mathrm{O}_{2}}$ to destabilize HIF-1 $\alpha$ the integrity of the cells is necessary. In additional experiments it was shown that $\mathrm{H}_{2} \mathrm{O}_{2}(0.1-1.0 \mathrm{mM})$ resulted in a dose-dependent decrease in the EPO mRNA expression induced by hypoxia which runs parallel to a decrease in $\mathrm{HIF}-1 \alpha$ binding to DNA and to a decrease in HIF-1 $\alpha$ protein, without modification of HIF- $1 \alpha$ mRNA levels or translation rate. It was also observed that extracts from hypoxic cells treated with $\mathrm{H}_{2} \mathrm{O}_{2}$ showed a normally high binding capacity to DNA. Those findings appear to indicate that the binding of HIF-1 $\alpha$ to DNA is controlled primarily at the level of HIF-1 $\alpha$ protein. In addition, Huang et al. (1996) also studied some of the modifications of HIF-1 $\alpha$ which might alter its binding to DNA. They found that oxidizing sulfhydryl reagents added to cell extracts inhibited the binding in a dose-dependent manner, this inhibition was reversible with reducing thiol reagents except when sulfhydryl alkylating agents were used. In addition, in a cotransfection experiment using a construct expressing thioredoxin under the control of the constitutive cytomegaloviral promoter and enhancer, along with another construct expressing luciferase under the control of the SV40 promoter and EPO-enhancer, they observed that overexpression of thioredoxin resulted in a potentiation of the expression of luciferase both in normoxic and hypoxic conditions, such potentiation appeared to be under the control of the HIF-1 binding because transfection with a mutated EPO enhancer, which was unable to bind HIF- $1 \alpha$, caused the loss of the response. As a whole the results would indicate that $\mathrm{H}_{2} \mathrm{O}_{2}$, like normoxia, produces modifications in the HIF-1 $\alpha$ molecule which force it to be directed to degradation, but which does not impede its binding to DNA. Alternatively, hypoxia promotes changes in $\mathrm{HIF}-1 \alpha$, which prevent its degradation, leading to accumulation of the transcription factor; the changes induced by hypoxia appear to be redox dependent because they can be mimicked by thioredoxin and counteracted by normoxia and $\mathrm{H}_{2} \mathrm{O}_{2}$; a similar conclusion was attained by Srinivas et al. (1999). An alternative interpretation to the findings of Huang et al., is that hypoxia (or the decrease of ROS) or the overexpression of thioredoxin produced changes in the degrading enzymes of the proteosoma which make them incapable of degrading a normal (or reduced) HIF $1 \alpha$.

However, in a series of experiments Chandel et al. (2000) found essentially the opposite: hypoxia and $\mathrm{CoCl}_{2}$, but not desferriexamine, increased ROS levels, and the three situations augmented the expression of a reporter gene under the control of the EPO-promoter as well as the amount of HIF- $1 \alpha$ protein. Inhibitors of the respiratory chain at the complex I, the thiol reductant pirrolidine dithiocarbamate, and overexpression of catalase, decreased hypoxic ROS levels and prevented the augmented expression of HIF-1 $\alpha$. The thiol reductant and the overexpression of catalase decreased the ROS levels increased by $\mathrm{CoCl}_{2}$ and 
also the expression of HIF-1 $\alpha$. Neither maneuver decreased the expression of the reporter gene or decreased the levels of HIF- $1 \alpha$ promoted by desferrioxamine. Addition of $\mathrm{H}_{2} \mathrm{O}_{2}$ and tert-butylhydroperoxide to normoxic cells promoted an increase of HIF-la protein as well as an increased expression of the reporter gene; these maneuvers were ineffective in cells overexpressing catalase. A phosphatase inhibitor and an inhibitor of phosphatidyl inositol 3-kinase abolished the stabilization of HIF-1 $\alpha$ induced by hypoxia, $\mathrm{CoCl}_{2}$ and desferrioxamine and a proteasome inhibitor was able to reverse those effects; because treatment of the cells with $\mathrm{H}_{2} \mathrm{O}_{2}$ was unable to prevent the effects of the phosphatase and kinase inhibitors, the authors concluded that ROS (including $\mathrm{H}_{2} \mathrm{O}_{2}$ ) act to stabilize HIF-1 $\alpha$ at a step prior to the action of the phosphatases and kinases. Desferrioxamine would produce the stabilization of HIF- $1 \alpha$ by a mechanism independent of ROS and would also act at a step prior to the phosphatases and kinases. Curiously, antimycin A, which increased ROS, did not induce the expression of the reporter gene or accumulation of HIF-1 $\alpha$. Chandel et al. (2000) state that it is because this mitochondrial inhibitor causes a smaller increase in ROS levels than hypoxia. However, it is difficult to understand how hypoxia can produce a more reduced state at the quinone pool than antimycin (see Fig. 2). In addition, antimycin A was applied in normoxia implying that the concentrations of $\mathrm{O}_{2}$ to accept the electrons from semiquinone are much higher than in hypoxia $\left(20 \% \mathrm{O}_{2}\right.$ vs. $1.5 \%$ in their experiments) and, therefore, the formation of $\mathrm{O}_{2}^{-} \cdot$ should be facilitated (Chance et al., 1979).

The controversy is obvious: to Huang et al. (1996) it is the decrease of ROS levels which causes the stabilization of HIF- $1 \alpha$ and to Chandel et al. (2000) it is the increase of ROS levels that does the same. Therefore, and in keeping with the statement of the third criterion, we do not know if we should be looking for a reduction or an oxidation of HIF- $1 \alpha$ as responsible for its stabilization. An additional aspect that we feel forced to restate at this point (which is seldom taken into account; see above) is that in the proposed signalling by ROS the subcellular localization of the ROS signal at the target place should be taken into con- sideration, otherwise a 'true' signaling would not exist, Finally, we agree with Halliwell and Gutteridge (2000) when they state regarding signaling by ROS: "one must be wary: cells in culture are usually hyperoxic and they lack many of the antioxidants they use in vivo...Cells adapt to live in culture. It is not impossible that, with tumor cell lines in particular, adaptations to favor growth may occur by using radicals to trigger pathways that are triggered by other means in vivo".

\subsubsection{Fourth criterion. Definition of the cellular} responses elicited by the effector activated by the changes in ROS levels

At this point in the article it is obvious that we can define the cellular responses elicited by the stimulus, i.e. hypoxia. However, we have serious difficulties in defining the cellular effects produced by the ROS level changes occurring during hypoxia because we do not know what those changes are. And even if we knew the changes in ROS levels produced during hypoxia we do not know if they are cause or consequence of activation of the effector and cellular responses.

Hypoxia in CB chemoreceptor cells and PASMC reduces the opening probability of the $\mathrm{O}_{2}$ regulated $\mathrm{K}^{+}$channels (see criterion 3) leading to cell depolarization, activation of voltage operated $\mathrm{Ca}^{2}+$ channels and release of neurotransmitters in chemoreceptor cells or contraction in smooth muscle cells (see Fig. 1). In criterion 3 we have already indicated that sulfhydryl reagents cause changes in the opening probability or amplitude of the currents that can be compatible with a decrease or an increase in ROS levels. Referring specifically to ROS, there are many studies in which $\mathrm{H}_{2} \mathrm{O}_{2}$ has been applied directly and its effects on several types of $\mathrm{K}^{+}$channels established. For example, Vega-Saenz de Miera and Rudy (1992) showed that $\mathrm{H}_{2} \mathrm{O}_{2}$ augmented the current carried by transient type $\mathrm{K}^{+}$channels (like those $\mathrm{O}_{2}$-sensitive channels in rabbit chemoreceptor cells) without affecting other $\mathrm{K}^{+}$ channels. Similarly the Kv3.3 present in airway chemoreceptors are activated by $\mathrm{H}_{2} \mathrm{O}_{2}$ (Wang et al., 1996; Fu et al., 2000). And there are many reports showing that $\mathrm{H}_{2} \mathrm{O}_{2}$ or tert-butylhydroper- 
oxide activate maxi-K $\mathrm{K}^{+}$(Hayabuchi et al. 1998; Shin et al., 2000; Guo et al., 2000; Barlow et al., 2000). All these data would favor the notion that hypoxia decreases ROS, and thereby hypoxia would decrease the activity of $\mathrm{K}^{+}$channels and depolarization would occur. However, there are studies in which it has been found that $\mathrm{H}_{2} \mathrm{O}_{2}$ inhibits $\mathrm{K}^{+}$channels. That is the case for maxi$\mathrm{K}^{+}$(DiChiara and Reinhart, 1997; Tang et al., 2001). These studies would be in agreement with the notion that hypoxia increases ROS levels and thereby causes inhibition of $\mathrm{K}^{+}$channels, cell depolarization and increased cell activity.

When we consider the effects of $\mathrm{H}_{2} \mathrm{O}_{2}$ on the overall response of the system, the study of Osanai et al. (1997) in the intact CB is very illustrative as they concluded that maneuvers aimed at altering endogenous $\mathrm{H}_{2} \mathrm{O}_{2}$, including exogenous $\mathrm{H}_{2} \mathrm{O}_{2}$ application, did not provide evidence for its supposedly critical role in $\mathrm{O}_{2}$ chemoreception. On the contrary, in the pulmonary circulation tertbutylhydroperoxide, $\mathrm{H}_{2} \mathrm{O}_{2}$ and ROS generating systems (i.e. perfusion of the lungs with xanthine plus xanthine oxidase) clearly inhibited hypoxic pulmonary vasoconstriction (Archer et al., 1986; Mohazzab and Wolin, 2000). In the case of EPOproducing cells we have commented in previous paragraphs on the apparently dual actions of $\mathrm{H}_{2} \mathrm{O}_{2}$ since on the one hand it inhibited EPO-production induced by hypoxia (Fandrey et al., 1994) and on the other hand it augmented the stabilization of HIF- $1 \alpha$ and promoted the expression of a reporter gene under the control of the EPO enhancer (Chandel et al., 2000). It should also be mentioned that Ueno et al. (1988) working with renal carcinoma EPO-producing cells and Ndele et al. (1996)) working with HEP 3B cells found that $\mathrm{H}_{2} \mathrm{O}_{2}$ and ROS generating systems increased EPO production while ROS scavengers have the opposite effects.

\subsubsection{Fifth criterion. The mechanism(s)} responsible for the inactivation of the ROS signal should be defined

Obviously we should consider here both possibilities: that the signal is a decrease and that the signal is an increase in ROS levels. In the first case, if a decrease in ROS levels is considered to be the result of a decrease in the activity of NADPH oxidase, the signal would disappear, i.e. normal ROS levels will be recovered, when $\mathrm{P}_{\mathrm{O}_{2}}$ returns to normoxic levels due to an increase in the activity of the enzyme by increased levels of substrate (it might also require a reassembly of the NADPH subunits promoted by unknown mechanisms; see second criterion). It is conceivable that chronic hypoxia would produce a downregulation of NADPH oxidase. A comparable mechanism to inactivate the ROS signal would be valid whether the decrease of ROS levels is considered to occur at the mitochondrial level, cytochrome P450, etc. If on the contrary, the signal is an increase in ROS levels, a given level of ROS should correspond to a given level of stimulation in order to obtain a response proportional to the intensity of the stimulus. This would imply that simultaneously to the activation of the mechanisms generating ROS there is a parallel activation of the mechanisms degrading them. If the stimulation is long lasting (e.g. chronic hypoxia) an upregulation of the mechanisms degrading ROS should be expected (Halliwell and Gutteridge, 1999). Obviously we are referring here to GSH, glutathione peroxidase, catalase and superoxide dismutase as the main systems to dispose ROS. There are not, to our knowledge, direct measurements of those ROS scavenger systems in the cell types we are discussing, however, there are some fragmentary data obtained in intact animals and humans exposed to high altitude. For example, Costa et al. (1993) obtained evidence indicating that in the liver of rats exposed to a simulated altitude of $4400 \mathrm{~m}$ there was a decrease in the rate of ROS production with a concomitant decrease in superoxide dismutase activity. However, Nakanishi et al. (1995) at a simulated altitude of $5500 \mathrm{~m}$ found a complex pattern of changes in those enzymes which was organ specific, and which was accompanied by an increase in lipid peroxidation and by a marked decrease in body weight of the animals attributed to an increased metabolic rate due to the hypobaric stress. Although it is difficult from these and similar data to reach sound conclusions, some experts in the area would suggest that there are risks of oxidative stress, independent of UV radiation, at high altitude (Simon-Schnass, 2000). 
3.1.6. Sixth criterion. Manipulation of ROS levels by alteration of glutathione levels or by the direct action of ROS scavengers should produce the predicted change in the cell response Overexpression and elimination of the enzymes scavenging ROS should produce the predicted change in the cell responses.

The interpretation of the data resulting from the manipulation of ROS and/or glutathione levels is not always straightforward due to the multiple targets of ROS. For example, the activation or mimicking of glutathione peroxidase (e.g. by administration of ebselen) would decrease the GSH/ GSSG ratio, just as a situation in which there is an increase in the rate of ROS production, but contrary to that situation ebselen will produce a decrease in the levels of $\mathrm{H}_{2} \mathrm{O}_{2}$. Since the decrease in the $\mathrm{GSH} / \mathrm{GSSG}$ ratio would tend to increase the opening probability of $\mathrm{K}^{+}$channels, and thereby to cause membrane hyperpolarization (and vasodilation, in the case of pulmonary circulation), and the decrease of $\mathrm{H}_{2} \mathrm{O}_{2}$ would tend to reduce the activity of guanylate cyclase, and thereby to inhibit $\mathrm{Ca}^{+}$dependent $\mathrm{K}^{+}$channels (and to produce vasoconstriction, in the case of pulmonary circulation), the overall effect could be very complex and difficult to define (see Wolin et al., 1999; Mohazzab and Wolin, 2000). In addition, and at least in the case of the lung, ROS can modify the metabolism of arachidonic acidderived metabolism in such a manner that an increase in ROS levels would augment the production of vasoconstrictor metabolites (Seeger et al., 1986; Sanderud et al., 1993; see Wolin et al., 1999).

Experiments in the CB directly focused on this last criterion have been performed in our laboratory very recently. We have measured GSH and GSSG levels in calf CB in normoxia, hypoxia and after treatment of the organs with $N$-acetylcysteine, a precursor of glutathione and direct scavenger of ROS and measured the release of catecholamines from chemoreceptor cells in those experimental situations (Obeso et al., 2000b). $N$ acetylcysteine would mimic a situation in which there is a decreased production of ROS and would oppose a situation of increased rate of ROS production. In other words, $N$-acetylcysteine would mimic hypoxia, if we accept that hypoxia decreases ROS levels, and would oppose hypoxia if we accept that it augments ROS levels. We found that hypoxia $\left(\mathrm{P}_{\mathrm{O}_{2}} \approx 46 \mathrm{mmHg}\right)$ did not alter the absolute levels or the GSH/GSSG quotients. $N$-acetylcysteine increased absolute glutathione levels by primarily increasing GSH; therefore, it increased the GSH/GSSG ratio. Yet $N$-acetylcysteine did not modify the basal normoxic or hypoxia-induced release of catecholamines suggesting that ROS are not critical in setting the hypoxic response.

In the case of the pulmonary circulation, Archer et al. (1986) showed that diamide (an agent that reacts with GSH and oxidizes it to GSSG) reduced the pressor response to hypoxia. Diamide would mimic a situation in which there is an increased production of ROS: it will cause a decrease in GSH/GSSG ratio and therefore the cellular power for scavenging of ROS leading to an increase in ROS levels. Both the decrease in GSH/GSSG ratio and the increase in ROS levels would tend to oppose the vasoconstriction provoked by hypoxia (see above). In agreement with the expected actions, pretreatment of the animals with $N$-acetylcysteine prevented the effects of diamide (Archer et al., 1986). In isolated perfused lungs, suplementation of the superfusates with catalase and superoxide dismutase neutralized the inhibition on hypoxic pulmonary vasoconstriction produced by ROS generating systems (xanthine/ xanthine oxidase) (Archer et al., 1986). But in another article it was reported that neither catalase nor superoxide dismutase modified the vasoconstriction elicited by hypoxia (Kjaeve et al., 1990), and more recently Weissmann et al. (1998) also found that superoxide dismutase was similarly ineffective. In this latter study several potential ROS scavengers were used and the results were inconclusive as from all the agents tested [superoxide dismutase, aminotriazole (a catalase inhibitor), tiron (a presumed superoxide scavenger) and nitro blue tetrazolium (another superoxide scavenger)] only nitro blue tetrazolium inhibited hypoxic pulmonary vasonstriction. In sum, the experiments aimed to alter ROS levels by manipulation of ROS scavenging systems in the lung have yielded conflicting results, and are therefore not conclusive with regard to the possible 
significance of ROS levels on hypoxic pulmonary vasoconstriction.

The data related to this criterion in EPO-producing cells are likewise inconclusive. In discussing the stabilization of HIF-1 $\alpha$ (criterion 3) we have focused on some discrepancies that might relate to this criterion. For example, we have mentioned that according to Huang et al. (1996) overexpression of thioredoxin potentiated the expression of a reporter gene under the control of EPO enhancer implying stabilization of HIF- $1 \alpha$. On the other hand, Chandel et al. (2000) reported that overexpression of catalase prevented stabilization of HIF- $1 \alpha$. A similar controversy exists regarding $\mathrm{H}_{2} \mathrm{O}_{2}$. Thus Fandrey et al. (1994) reported that $\mathrm{H}_{2} \mathrm{O}_{2}$ inhibited the production of EPO induced by hypoxia and that catalase reversed the inhibition produced by $\mathrm{H}_{2} \mathrm{O}_{2}$. On the contrary, Ueno et al. (1988), Ndele et al. (1996) (see also Chandel et al., 2000) reported that catalase inhibited the EPO production stimulated by $\mathrm{H}_{2} \mathrm{O}_{2}$ and by ROS-generating systems glucose/glucose oxidase and xanthine/xanthine oxidase.

\section{Conclusion}

With the available information we do not know if hypoxia increases or decreases ROS levels, and therefore we do not know if the putative role of ROS, i.e. to inhibit $\mathrm{K}^{+}$channels in the $\mathrm{CB}$ chemoreceptor cells and in PASMC and to stabilize HIF-1 $\alpha$ in EPO-producing cells, is the result of the reduction or the oxidation of the $\mathrm{K}^{+}$ channel proteins or HIF- $1 \alpha$. The uncertainties remain when we consider the effects of agents that increase or decrease ROS levels on the responses of CB chemoreceptor cells, PASMC and EPOproducing cells. There are several mitochondrial poisons, which have opposite effects on the rate of ROS production and levels, and yet all activate chemoreceptor cells and PASMC in normoxia and potentiate their hypoxic response. Similarly, there are mitochondrial agents that can either decrease or increase ROS levels, yet they fail to alter normoxic EPO production, implying that neither the decrease nor the increase in ROS levels mimic hypoxia. The panorama is not clarified by the use of agents or experimental maneuvers that alter the rate of ROS scavenging. There are reports indicating that ROS scavenging enzymes or drugs tend to mimic hypoxia and reports indicating the opposite, both, in PASMC and in EPOproducing cells. In the $\mathrm{CB}$ chemoreceptor cells the scavenging of ROS did not alter the normoxic output of the cells nor their hypoxic response. In sum, the available information on $\mathrm{O}_{2}$-sensing/hypoxic transduction does not support an unequivocal role for ROS in those cellular processes. The possibility exists that many of the contradictory findings, which have been obtained in tumor cell lines, represent peculiarities of particular clones used in different laboratories. In any case, it should always be kept in mind that the metabolic properties of tumor cells might differ substantially from the parental normal cells. In designing experiments, it should also be remembered that maneuvers aimed at manipulating ROS can do more than simply alter ROS levels: special care should be taken in selecting the potentially pleiotropic ROS scavengers and ROS mimetics.

\section{Acknowledgements}

Supported by Spanish DGICYT Grant PB97/ 0400. Thanks to Professor Benito Herreros for critical reading.

\section{References}

Acker, H., 1994a. Cellular oxygen sensors. Ann. New York Acad. Sci. 718, 3-10.

Acker, H., 1994b. Mechanisms and meaning of cellular oxygen sensing in the organism. Respir. Physiol. 95, 1-10.

Acker, H., Xue, D., 1995. Mechanisms of $\mathrm{O}_{2}$ sensing in the carotid body in comparison with other $\mathrm{O}_{2}$-sensing cells. News Physiol. Sci. 10, 211-215.

Almaraz, L., Gonzalez, C., Obeso, A., 1986. Effects of high potassium on the release of $\mathrm{H}$-dopamine from the cat carotid body in vitro. J. Physiol. London 379, 293-307.

Anichkov, S.V., Belen'kii, M.L., 1963. Pharamacology of the Carotid Body Chemoreceptors. MacMillan, New York, USA.

Archer, S.L., Will, J.A., Weir, E.K., 1986. Redox status in the control of pulmonary vascular tone. Herz 11, 127-141. 
Archer, S.L., Nelson, D.P., Weir, E.K., 1989. Simultaneous measurement of $\mathrm{O}_{2}$ radicals and pulmonary vascular reactivity in rat lung. J. Appl. Physiol. 67, 1903-1911.

Archer, S.L., Huang, J., Henry, T., Peterson, D., Weir, E.K., 1993. A redox-based $\mathrm{O}_{2}$ sensor in rat pulmonary vasculature. Circ. Res. 73, 1100-1112.

Archer, S.L., Huang, J.M., Hampl, V., Nelson, D.P., Shultz, P.J., Weir, E.K., 1994. Nitric oxide and cGMP cause vasorelaxation by activation of a charybdotoxin-sensitive $\mathrm{K}$ channel by cGMP -dependent protein kinase. Proc. Natl. Acad. Sci. USA 91, 7583-7597.

Archer, S.L., Souil, E., Dinh-Xuan, A.T., Schremmer, B., Mercier, J.C., El Yaagoubi, A., Nguyen-Huu, L., Reeve, H.L., Hampl, V., 1998. Molecular identification of the role of voltage-gated $\mathrm{K}^{+}$channels, $\mathrm{Kvl} .5$ and $\mathrm{Kv} 2.1$, in hypoxic pulmonary vasoconstriction and control of resting membrane potential in rat pulmonary artery myocytes. J. Clin. Invest. 101, 2319-2330.

Archer, S.L., Reeve, H.L., Michelakis, E., Puttagunta, L., Waite, R., Nelson, D.P., Dinauer, M.C., Weir, E.K., 1999. $\mathrm{O}_{2}$ sensing is preserved in mice lacking the gp91 phox subunit of NADPH oxidase. Proc. Natl. Acad. Sci. USA 96, 7944-7949.

Archer, S.L., Weir, E.K., Reeve, H.L., Michelakis, E., 2000. Molecular identification of $\mathrm{O}_{2}$ sensors and $\mathrm{O}_{2}$-sensitive potassium channels in the pulmonary circulation. Adv. Exp. Med. Biol. 475, 219-240.

Barlow, R.S., El-Mowafy, A.M., White, R.E., 2000. $\mathrm{H}_{2} \mathrm{O}_{2}$ opens $\mathrm{BK}(\mathrm{Ca})$ channels via the $\mathrm{PLA}_{2}$-arachidonic acid signaling cascade in coronary artery smooth muscle. Am. J. Physiol. 279, H475-H483.

Beckman, J.S., Koppenol, W.H., 1996. Nitric oxide, superoxide, and peroxynitrite: the good, the bad, and ugly. Am. J. Physiol. 271, C1424-C1437.

Bolotina, V.M., Najibi, S., Palacino, J.J., Pagano, P.J., Cohen, R.A., 1994. Nitric oxide directly activates calcium-dependent potassium channels in vascular smooth muscle. Nature 368, 850-853.

Boveris, A., Costa, L.E., Poderoso, J.J., Carreras, M.C., Cadenas, E., 2000. Regulation of mitochondrial respiration by oxygen and nitric oxide. Ann. New York Acad. Sci. USA $899,121-135$.

Buckler, K.J., 1997. A novel oxygen-sensitive potassium current in rat carotid body type I cells. J. Physiol. London 498, 649-662.

Buckler, K.J., 1999. Background leak $\mathrm{K}^{+}$-currents and oxygen sensing in carotid body type I cells. Respir. Physiol. 115, $179-187$.

Buckler, K.J., Williams, B.A., Honore, E., 2000. An oxygen-, acid- and anaesthetic-sensitive TASK-like background potassium channel in rat arterial chemoreceptor cells. J. Physiol. London 525, 135-142.

Chance, B., Sies, H., Boveris, A., 1979. Hydroperoxide metabolism in mammalian organs. Physiol. Rev. 59, 527605.

Chandel, N.S., Schumacker, P.T., 1999. Cells depleted of mitochondrial DNA (rho0) yield insight into physiological mechanisms. FEBS Lett. 454, 173-176.
Chandel, N.S., Schumacker, P.T., 2000. Cellular oxygen sensing by mitochondria: old questions, new insight. J. Appl. Physiol. 88, 1880-1889.

Chandel, N.S., Maltepe, E., Goldwasser, E., Mathieu, C.E., Simon, M.C., Schumacker, P.T., 1998. Mitochondrial reactive oxygen species trigger hypoxia-induced transcription. Proc. Natl. Acad. Sci. USA 95, 11715-11720.

Chandel, N.S., McClintock, D.S., Feliciano, C.E., Wood, T.M., Melendez, J.A., Rodriguez, A.M., Schumacker, P.T., 2000. Reactive oxygen species generated at mitochondrial complex III stabilize hypoxia-inducible factor- $1 \alpha$ during hypoxia: a mechanism of $\mathrm{O}_{2}$ sensing. J. Biol. Chem. 275, $25130-25138$.

Chou, C.L., Shirahata, M., 1996. Two types of voltage-gated $\mathrm{K}^{+}$channels in carotid body cells of adult cats. Brain Res. 742, 34-42.

Costa, L.E., Llesuy, S., Boveris, A., 1993. Active oxygen species in the liver of rats submitted to chronic hypobaric hypoxia. Am. J. Physiol. 264, C1395-C1400.

Cross, A.R., Henderson, L., Jones, O.T.G., Delpiano, M.A., Hentschel, J., Acker, H., 1990. Involvement on NAD(P)H oxidase as a $\mathrm{P}_{\mathrm{O}_{2}}$ sensor protein in the rat carotid body. Biochem. J. 272, 743-747.

Dang, P.M., Cross, A.R., Babior, B.M., 2001. Assembly of the neutrophil respiratory burst oxidase: a direct interaction between p67PHOX and cytochrome b558. Proc. Natl. Acad. Sci. USA 98, 3001-3005.

Davies, M.J., Dean, R.T., 1997. Radical-Mediated Protein Oxidation. From Chemistry to Medicine. Oxford Science Publications, Oxford, UK, pp. 25-120.

DiChiara, T.J., Reinhart, P.H., 1997. Redox modulation of hslo $\mathrm{Ca}^{2-}$ activated $\mathrm{K}^{+}$channels. J. Neurosci. 17, 49424955.

Duchen, M.R., Biscoe, T.J., 1992. Relative mitochondrial membrane potential and $\left[\mathrm{Ca}^{2+}\right]_{i}$ in type I cells isolated from the rabbit carotid body. J. Physiol. London 450, $33-61$.

Duranteau, J., Chandel, N.S., Kulisz, A., Shao, Z., Schumacker, P.T., 1998. Intracellular signaling by reactive oxygen species during hypoxia in cardiomyocytes. J. Biol. Chem. 273, 11619-11624.

Dvorakova, M., Hohler, B., Vollerthun, R., Fischbach, T., Kummer, W., 2000. Macrophages: a major source of cytochrome b558 in the rat carotid body. Brain Res. 852, 349-354.

Ehleben, W., Porwol, T., Fandrey, J., Kummer, W., Acker, H., 1997. Cobalt and desferrioxamine reveal crucial members of the oxygen sensing pathway in HepG2 cells. Kidney Int. 51, 483-491.

Eu, J.P., Sun, J., Xu, L., Stamler, J.S., Meissner, G., 2000. The skeletal muscle calcium release channel: coupled $\mathrm{O}_{2}$ sensor and NO signaling functions. Cell 102, 499-509.

Fandrey, J., Frede, S., Jelkmann, W., 1994. Role of hydrogen peroxide in hypoxia-induced erythropoietin production. Biochem. J. 303, 507-510.

Fandrey, J., Frede, S., Ehleben, W., Porwol, T., Acker, H., Jelkmann, W., 1997. Cobalt chloride and desferrioxamine 
antagonize the inhibition of erythropoietin production by reactive oxygen species. Kidney Int. 51, 492-496.

Fidone, S., Gonzalez, C, 1996. Initiation and control of chemoreceptor activity in the carotid body. In: Fishman, A.P. (Ed.), Handbook of Physiology. The Respiratory System. American Physiology Society, Bethesda, MD, pp. 247-312.

Firth, J.D., Ebert, B.L., Pugh, C.W., Ratcliffe, P.J., 1994. Oxygen-regulated control elements in the phosphogly cerate kinase 1 and lactate dehydrogenase A genes: similarities with the erythropoietin $3^{\prime}$ enhancer. Proc. Natl. Acad. Sci. USA 91, 6496-6500.

Fu, X.W., Nurse, C.A., Wang, Y.T., Cutz, E., 1999. Selective modulation of membrane currents by hypoxia in intact airway chemoreceptors from neonatal rabbit. J. Physiol. London 514, 139-150.

Fu, X.W., Wang, D., Nurse, C.A., Dinauer, M.C., Cutz, E., 2000. NADPH oxidase is an O2 sensor in airway chemoreceptors: evidence from $\mathrm{K}^{+}$current modulation in wild-type and oxidase-deficient mice. Proc. Natl. Acad. Sci. USA 97, 4374-4379.

Gabig, T.G., Schervish, E.W., Santinga, J.T., 1982. Functional relationship of the cytochrome $\mathrm{b}$ to the superoxide-generating oxidase of human neutrophils. J. Biol. Chem. 257, 4114-4119.

Ganfornina, M.D., López-Barneo, J., 1991. Single K ${ }^{+}$channels in membrane patches of arterial chemoreceptor cells are modulated by $\mathrm{O}_{2}$ tension. Proc. Natl. Acad. Sci. USA 88, 2927-2930.

Gassmann, M., Chilov, D., Wenger, R.W., 2000. Regulation of the hypoxia-inducible factor- $1 \alpha$. ARNT is not necessary for hypoxic induction of HIF-1 $\alpha$ in the nucleus. Adv. Exp. Med. Biol. 475, 87-99.

Geiszt, M., Kopp, J.B., Varnai, P., Leto, T.L., 2000. Identification of renox, an NAD(P)H oxidase in kidney. Proc. Natl. Acad. Sci. USA 97, 8010-8014.

Gleadle, J.M., Ebert, B.L., Ratcliffe, P.J., 1995. Diphenyleneiodonium inhibits the induction of erythropoietin and other mammalian genes by hypoxia. Eur. J. Biochem. 234, 92-99.

Gnaiger, E., Mendez, G., Hand, S.C., 2000. High phosphorylation efficiency and depression of uncoupled respiration in mitochondria under hypoxia. Proc. Natl. Acad. Sci. USA 97, 11080-11085.

Goldberg, M.A., Glass, G.A., Cunningham, J.M., Bunn, H.F., 1987. The regulated expression of erythropoietin by two human hepatoma cell lines. Proc. Natl. Acad. Sci. USA 84, 7972-7976.

Goldberg, M.A., Dunning, S.P., Bunn, H.F., 1988. Regulation of the erythropoietin gene: evidence that the oxygen sensor is a heme protein. Science 242, 1412-1415.

Gonzalez, C., 1998. Sensitivity to physiologic hypoxia. In: Lopez-Barneo, J., Weir, E.K. (Eds.), Oxygen regulation of Ion Channels and Gene Expression. Futura Publishing Co Inc, Armonk, NY, pp. 321-336.

Gonzalez, C., Almaraz, L., Obeso, A., Rigual, R., 1992. Oxygen and acid chemoreception in the carotid body chemoreceptors. Trends Neurosci. 15, 146-153.
Gonzalez, C., Almaraz, L., Obeso, A., Rigual, R., 1994. Carotid body chemoreceptors: from natural stimuli to sensory discharges. Physiol. Rev. 74, 829-898.

Gorlach, A., Holtermann, G., Jelkmann, W., Hancock, J.T., Jones, S.A., Jones, O.T., Acker, H., 1993. Photometric characteristics of haem proteins in erythropoietin-producing hepatoma cells (HepG2). Biochem. J. 290, 771-776.

Gorlach, A., Fandrey, J., Holtermann, G., Acker, H., 1994. Effects of cobalt on haem proteins of erythropoietin-producing HepG2 cells in multicellular spheroid culture. FEBS Lett. 348, 216-218.

Grimminger, F., Weissmann, N., Spriestersbach, R., Becker, E., Rosseau, S., Seeger, W., 1995. Effects of NADPH oxidase inhibitors on hypoxic vasoconstriction in bufferperfused rabbit lungs. Am. J. Physiol. 268, L747-L752.

Guo, J., Giles, W.R., Ward, C.A., 2000. Effect of hydrogen peroxide on the membrane currents of sinoatrial node cells from rabbit heart. Am. J. Physiol. 279, H992-H999.

Halliwell, B., Gutteridge, J.M.C., 1999. Free Radicals in Biology and Medicine, third ed. Oxford University Press, Oxford UK.

Halliwell, B., Gutteridge, J.M.C., 2000. Free radicals and antioxidant in the year, a historical look to the future. Ann. NewYork Acad. Sci. 899, 136-147.

Hayabuchi, Y., Nakaya, Y., Matsuoka, S., Kuroda, Y., 1998. Hydrogen peroxide-induced vascular relaxation in porcine coronary arteries is mediated by $\mathrm{Ca}^{2+}$-activated $\mathrm{K}^{+}$channels. Heart Vessels 13, 9-17.

Hochachka, P.W., Land, S.C., Buck, L.T., 1997. Oxygen sensing and signal transduction in metabolic defense against hypoxia: lessons from vertebrate facultative anaerobes. Comp. Biochem. Physiol. A Comp. Physiol. 118, $23-29$

Hoshi, T., Heinemann, S.H., 2001. Regulation of cell function by methionine oxidation and reduction. J. Physiol. London 531, 1-11.

Huang, L.E., Arany, Z., Livingston, D.M., Bunn, H.F., 1996. Activation of hypoxia-inducible transcription factor depends primarily upon redox-sensitive stabilization of its alpha subunit. J. Biol. Chem. 271, 32253-32259.

Iizuka, T., Kanegasaki, S., Makino, R., Tanaka, T., Ishimura, Y., 1985. Studies on neutrophil b-type cytochrome in situ by low temperature absorption spectroscopy. J. Biol. Chem. 260, 12049-12053.

Jelkmann, W., 1992. Erythropoietin: structure, control of production, and function. Physiol. Rev. 72, 449-489.

Joels, N., Neil, E., 1968. The idea of a sensory transmitter. In: Torrance, R.W. (Ed.), Arterial Chemoreceptors. Blackwell, Oxford, pp. 153-178.

Kietzmann, T., Fandrey, J., Acker, H., 2000. Oxygen radicals as messengers in oxygen-dependent gene expression. News Physiol. Sci. 15, 202-208.

Kjaeve, J., Veel, T., Bjertnaes, L., 1990. Allopurinol inhibits hypoxic pulmonary vasoconstriction. Role of toxic oxygen metabolites. Acta Anaesthesiol. Scand. 34, 384-388.

Kummer, W., Acker, H., 1995. Immunohistochemical demonstration of four subunits of neutrophil NAD(P)H oxidase 
in type I cells of carotid body. J. Appl. Physiol. 78, 1904-1909.

Lahiri, S., Iturriaga, R., Mokashi, A., Ray, D.K., Chugh, D., 1993. CO reveals dual mechanisms of $\mathrm{O}_{2}$ chemoreception in the cat carotid body. Respir. Physiol. 94, 227-240.

Lander, H.M., 1997. An essential role for free radicals and derived species in signal transduction. FASEB J. 11, 118124.

Liu, H., Moczydlowski, E., Haddad, G.G., 1999. O 2 deprivation inhibits $\mathrm{Ca}^{2+}$-activated $\mathrm{K}^{+}$channels via cytosolic factors in mice neocortical neurons. J. Clin. Invest. 104, $577-588$.

López-Barneo, J., López-López, J.R., Ureña, J., Gonzalez, C., 1988. Chemotransduction in the carotid body: $\mathrm{K}^{+}$current modulated by $\mathrm{P}_{\mathrm{O}_{2}}$ in type $\mathrm{I}$ chemoreceptor cells. Science 241, 580-582.

López-Barneo, J., Pardal, R., Montoro, R.J., Smani, T., Garcia-Hirschfeld, J., Urena, J., 1999. $\mathrm{K}^{+}$and $\mathrm{Ca}^{2+}$ channel activity and cytosolic $\left[\mathrm{Ca}^{2+}\right]$ in oxygen-sen sing tissues. Respir. Physiol. 115, 215-227.

López-López, J.R., Gonzalez, C., 1992. Time course of $\mathrm{K}^{+}$ current inhibition by low oxygen in chemoreceptors cells of adult rabbit carotid body. Effects of carbon monoxide. FEBS Lett. 299, 251-254.

López-López, J., Gonzalez, C., Ureña, J., López-Barneo, J., 1989. Low $\mathrm{P}_{\mathrm{O}_{2}}$ selectively inhibits $\mathrm{K}^{+}$channel activity in chemoreceptor cells of the mammalian carotid body. J. Gen. Physiol. 93, 1001-1015.

López-López, J.R., Gonzalez, C., Perez-Garcia, M.T., 1997. Properties of ionic currents from isolated adult rat carotid body chemoreceptor cells. Effects of hypoxia. J. Physiol. London. 499, 429-441.

Marshall, B.E., Marshall, C., Frasch, F., Hanson, C.W., 1994. Role of hypoxic pulmonary vasoconstriction in pulmonary gas exchange and blood flow distribution. 1. Physiologic concepts. Intensive Care Med. 20, 291-297.

Marshall, C., Mamary, A.J., Verhoeven, A.J., Marshall, B.E., 1996. Pulmonary artery NADPH-oxidase is activated in hypoxic pulmonary vasoconstriction. Am. J. Respir. Cell Mol. Biol. 15, 633-644.

Matsumoto, S., Nagamine, T., Yakata, H., Kohno, M., 1987. Alteration of chemoreflex phrenic responses by oligomycin in the rabbit. Arch. Int. Pharmacodyn. Ther. 286, 136144.

McLennan, H., 1963, Synaptic transmission. Saunders. Philadelphia, USA.

Mohazzab, K.M., Wolin, M.S., 2000. Oxidant signalling and vascular oxygen sensing. Role of $\mathrm{H}_{2} \mathrm{O}_{2}$ in responses of the bovine pulmonary artery to changes in $\mathrm{P}_{\mathrm{O}_{2}}$. Adv. Exp. Med. Biol. 475, 249-258.

Mulligan, E., Lahiri, S., 1982. Separation of carotid body chemoreceptor responses to $\mathrm{O}_{2}$ and $\mathrm{CO}_{2}$ by oligomycin and by antimycin A. Am. J. Physiol. 242, C200-C206.

Nakanishi, K., Tajima, F., Nakamura, A., Yagura, S., Ookawara, T., Yamashita, H., Suzuki, K., Taniguchi, N., Ohno, H., 1995. Effects of hypobaric hypoxia on antioxidant enzymes in rats. J. Physiol. London 489, 869-876.
Ndele, J.K., Yoshioka, K., Fisher, J.W., 1996. Hydrogen peroxide in the regulation of erythropoietin (Epo) gene expression in hepatocellular carcinoma cells. East Afr. Med. J. 73, 143-146.

Obeso, A., 1984. Hipotesis metabolica de quimiotansduccion: hechos experimentales. (Ph. D Thesis). Universidad de Valladolid, Valladolid, Spain.

Obeso, A., Almaraz, L., Gonzalez, C., 1989a. Effects of cyanide and uncouplers on chemoreceptor activity and ATP content of the cat carotid body. Brain Res. 481, 250-257.

Obeso, A., Gonzalez, C., Dinger, B., Fidone, S., 1989b. Metabolic activation of carotid body glomus cells by hypoxia. J. Appl. Physiol. 67, 484-487.

Obeso, A., Gonzalez, C., Rigual, R., Dinger, B., Fidone, S., 1993. Effect of low $\mathrm{O}_{2}$ on glucose uptake in rabbit carotid body. J. Appl. Physiol. 74, 2387-2393.

Obeso, A., Rocher, A., Herreros, B., Gonzalez, C., 1997. Oxygen consumption and energy metabolism of the carotid body. In: Gonzalez, C. (Ed.), The Carotid Body Chemoreceptors. Springer, NY, pp. 31-45.

Obeso, A., Gomez-Niño, A., Gonzalez, C., 1999. Inhibition of NADPH oxidase does and not interfere with low $\mathrm{P}_{\mathrm{O}_{2}}$ transduction in chemoreceptor cells. Am. J. Physiol. 276, C593-C601.

Obeso, A., Sanz-Alfayate, G., Agapito, M.T., Gonzalez, C., 2000a. Significance of ROS in oxygen chemoreception in the carotid body chemoreception. Apparent lack of a role for NADPH oxidase. Adv. Exp. Med. Biol. 475, 425-434.

Obeso, A., Sanz-Alfayate, G., Agapito, M.T., Gonzalez, C., 2000b. Glutathione levels and GSH-GSSG ratios in the carotid body and oxygen sensing in chemoreceptor cells. High Altitude Med. Biol. 1, 255.

Ohkuma, S., Katsura, M., 2001. Nitric oxide and peroxynitrite as factors to stimulate neurotransmitter release in the CNS. Prog. Neurobiol. 64, 97-108.

Osanai, S., Mokashi, A., Rozanov, C., Buerk, D.G., Lahiri, S., 1997. Potential role of $\mathrm{H}_{2} \mathrm{O}_{2}$ in chemoreception in the cat carotid body. J. Auton. Nerv. Syst. 63, 39-45.

Osipenko, O.N., Tate, R.J., Gurney, A.M., 2000. Potential role for kv3.1b channels as oxygen sensors. Circ. Res. 86, $534-540$.

Paky, A., Michael, J.R., Burke-Wolin, T.M., Wolin, M.S., Gurtner, G.H., 1993. Endogenous production of superoxide by rabbit lungs: effects of hypoxia or metabolic inhibitors. J. Appl. Physiol. 74, 2868-2874.

Patel, A.J., Lazdunski, M., Honore, E., 1997. Kv2.1/Kv9.3, a novel ATP-dependent delayed-rectifier $\mathrm{K}^{+}$channel in oxygen-sensitive pulmonary artery myocytes. EMBO J. 16, 6615-6625.

Peers, C., 1990. Hypoxic suppression of $\mathrm{K}^{+}$currents in type I carotid body cells: selective effect on the $\mathrm{Ca}^{2+}$-activated $\mathrm{K}^{+}$current. Neurosci. Lett. 119, 253-256.

Pérez-García, M.T., López-López, J.R., 2000. Are Kv channels the essence of $\mathrm{O}_{2}$ sensing. Circ. Res. 86, 490-491.

Perez-García, M.T., López-López, J.R., Gonzalez, C., 1999. $\mathrm{Kv} \beta 1.2$ subunit $\mathrm{i}$ modulates the sensitivity to hypoxia of cloned voltage-gated $\mathrm{K}^{+}$channels in a subfamily-specific manner. J. Gen. Physiol. 113, 897-907. 
Pérez-García, M.T., López-López, J.R., Riesco, A.M., Hoppe, U., Gonzalez, C., Marban, E., Johns, D.C., 2000. Supression of transient outward $\mathrm{K}^{+}$currents in chemoreceptor cells of the rabbit carotid body by viral gene transfer of inducible dominant negative Kv4.3 constructs. J. Neurosci. 20, 5689-5695.

Post, J.M., Hume, J.R., Archer, S.L., Weir, E.K., 1992. Direct role for potassium channel inhibition in hypoxic pulmonary vasoconstriction. Am. J. Physiol. 262, C882-C890.

Pugh, C.W., Tan, C.C., Jones, R.W., Ratcliffe, P.J., 1991. Functional analysis of an oxygen-regulated transcriptional enhancer lying 3' to the mouse erythropoietin gene. Proc. Natl. Acad. Sci. USA 88, 10553-10557.

Punchard, N.A., Kelly, F.J., 1996. Free Radicals. A Practical Approach. IRL Press-Oxford University Press, Oxford, UK, pp. 1-8.

Ratcliffe, P.J., Ebert, B.L., Ferguson, D.J., Firth, J.D., Gleadle, J.M., Maxwell, P.H., Pugh, C.W., 1995. Regulation of the erythropoietin gene. Nephrol. Dial. Transplant. 10 (Suppl 29), 18-27.

Richalet, J.P., 1997. Oxygen sensors in the organism: examples of regulation under altitude hypoxia in mammals. Comp. Biochem. Physiol. A Physiol. 118, 9-14.

Riesco, A., Peréz-Garcia, M.T., Gonzalez, C., López-López, J.R., 2001. $\mathrm{Ca}^{2+}$-dependent $\mathrm{K}^{+}$channels are modulated by hypoxia and $\mathrm{CO}$ in isolated membrane patches of rat chemoreceptor cells. Biophys. J. 80, 206a.

Rocher, A., Obeso, A., Herreros, B., Gonzalez, C., 1988. Activation of the release of dopamine in the carotid body by veratridine. Evidence for the presence of voltage-dependent $\mathrm{Na}^{+}$channels in type I cells. Neurosci. Lett. 94, 274-278.

Roy, A., Rozanov, C., Mokashi, A., Daudu, P., Al-mehdi, A.B., Shams, H., Lahiri, S., 2000. Mice lacking in gp91 phox subunit of NAD(P)H oxidase showed glomus cell $\left[\mathrm{Ca}^{2+}\right]_{\mathrm{i}}$ and respiratory responses to hypoxia. Brain Res. 872, 188-193.

Ruppersberg, J.P., Stocker, M., Pongs, O., Heinemann, S.H., Frank, R., Koenen, M., 1991. Regulation of fast inactivation of cloned mammalian IK(A) channels by cysteine oxidation. Nature 352, 711-714.

Sanderud, J., Bjoro, K., Saugstad, O.D., 1993. Oxygen radicals stimulate thromboxane and prostacyclin synthesis and induce vasoconstriction in pig lungs. Scand. J. Clin. Lab. Invest. 53, 447-455.

Seeger, W., Suttorp, N., Schmidt, F., Neuhof, H., 1986. The glutathione redox cycle as a defense system against hydrogen-peroxide-induced prostanoid formation and vasoconstriction in rabbit lungs. Am. Rev. Respir. Dis. 133, 1029-1036.

Semenza, G.L., 1994. Regulation of erythropoietin production. New insights into molecular mechanisms of oxygen homeostasis. Hematol. Oncol. Clin. North Am. 8, 863884.

Semenza, G.L., 1999. Perspectives on oxygen sensing. Cell 98, $281-284$.
Semenza, G.L., 2000. Chairman's summary: mechanisms of oxygen homeostasis, circa 1999. Adv. Exp. Med. Biol. 475, 303-310.

Shin, J.H., Lee, J.E., Park, J.M., Suh, C.K., 2000. T-butyl hydrogen peroxide increases the activities of the Maxi-K channels of rat brain. Life Sci. 67, 2485-2491.

Simon-Schnass, I.M., 2000. Risk of oxidative stress at high altitude and possible benefit of antioxidant supplementation. In: Sen, C.K., Packer, L., Hannimen, O. (Eds.), Handbook of Oxidants and Antioxidants in Exercise. Elsevier, Amsterdam, The Netherlands, pp. 555-577.

Soh, R., Jung, W., Uhm, D.Y., Chung, S., 2001. Modulation of large conductance calcium-activated potassium channels from rat hippocampal neurons by glutathione. Neurosci. Lett. 298, 115-118.

Srinivas, V., Zhang, L.P., Zhu, X.H., Caro, J., 1999. Characterization of an oxygen/redox-dependent degradation domain of hypoxia-inducible factor alpha (HIF- $\alpha)$ proteins. Biochem. Biophys. Res. Commun. 260, 557-561.

Tamayo, L., López-López, J.R., Castañeda, J., González, C., 1997. Carbon monoxide inhibits hypoxic pulmonary vasoconstriction by a cGMP-independent mechanism. Pflügers. Arch. Eur. J. Physiol. 434, 698-704.

Tan, C.C., Ratcliffe, P.J., 1991. Effect of inhibitors of oxidative phosphorylation on erythropoietin mRNA in isolated perfused rat kidneys. Am. J. Physiol. 261, F982-F987.

Tang, X.D., Daggert, H., Hanner, M., Garcia, M.L., McManus, O.B., Brot, N., Weissbach, H., Heinemann, S.H., Hoshi, T., 2001. Oxidative regulation of large conductance calcium-activated potassium channels. J. Gen. Physiol. $117,253-274$.

Thomas, H.M., Carson, R.C., Fried, E.D., Novitch, R.S., 1991. Inhibition of hypoxic pulmonary vasoconstriction by diphenyleneiodonium. Biochem. Pharmacol. 42, R9-R12.

Thompson, J.S., Jones, R.D., Rogers, T.K., Hancock, J., Morice, A.H., 1998. Inhibition of hypoxic pulmonary vasoconstriction in isolated rat pulmonary arteries by diphenyleneiodonium (DPI). Pulm. Pharmacol. Ther. 11, 71-75.

Thuringer, D., Findlay, I., 1997. Contrasting effects of intracellular redox couples on the regulation of maxi- $\mathrm{K}^{+}$channels in isolated myocytes from rabbit pulmonary artery. $\mathbf{J}$. Physiol. London 500, 583-592.

Ueno, M., Brookins, J., Beckman, B.S., Fisher, J.W., 1988. Effects of reactive oxygen metabolites on erythropoietin production in renal carcinoma cells. Biochem. Biophys. Res. Commun. 154, 773-780.

Vega-Saenz de Miera, E., Rudy, B., 1992. Modulation of $\mathrm{K}^{+}$ channels by hydrogen peroxide. Biochem. Biophys. Res. Commun. 186, 1681-1687.

Verna, A., Talib, N., Roumy, M., Pradet, A., 1990. Effects of metabolic inhibitors and hypoxia on the ATP, ADP and AMP content of the rabbit carotid body in vitro: the metabolic hypothesis in question. Neurosci. Lett. 116, 156-161.

Wang, G.L., Semenza, G.L., 1993a. Characterization of hypoxia-inducible factor 1 and regulation of DNA binding activity by hypoxia. J. Biol. Chem. 268, 21513-21558. 
Wang, G.L., Semenza, G.L., 1993b. General involvement of hypoxia-inducible factor 1 in transcriptional response to hypoxia. Proc. Natl. Acad. Sci. USA 90, 4304-4308.

Wang, D., Youngson, C., Wong, V., Yeger, H., Dinauer, M.C., Vega-Saenz Miera, E., Rudy, B., Cutz, E., 1996. NADPH-oxidase and a hydrogen peroxide-sensitive $\mathrm{K}^{+}$ channel may function as an oxygen sensor complex in airway chemoreceptors and small cell lung carcinoma cell lines. Proc. Natl. Acad. Sci. USA 93, 13182-13187.

Weir, E.K., Archer, S.L., 1995. The mechanism of acute hypoxic pulmonary vasoconstriction: the tale of two channels. FASEB J. 9, 183-189.

Weir, E.K., Wyatt, C.N., Reeve, H.L., Archer, S.L., Peers, C., 1994. Diphenyleneiodonium inhibits both $\mathrm{K}^{+}$and $\mathrm{Ca}^{2+}$ currents in isolated pulmonary artery smooth muscle cells. J. Appl. Physiol. 76, 2611-2615.

Weissmann, N., Grimminger, F., Voswinckel, R., Conzen, J., Seeger, W., 1998. Nitro blue tetrazolium inhibits but does not mimic hypoxic vasoconstriction in isolated rabbit lungs. Am. J. Physiol. 274, L721-L727.

Wenger, R.H., Marti, H.H., Schuerer-Maly, C.C., Kvietikova, I., Bauer, C., Gassmann, M., Maly, F.E., 1996. Hypoxic induction of gene expression in chronic granulomatous disease-derived B-cell lines: oxygen sensing is independent of the cytochrome b558-containing nicotinamide adenine dinucleotide phosphate oxidase. Blood 87, 756-761.

Wolin, M.S., Burke-Wolin, T.M., Mohazzab-H, K.M., 1999. Roles for $\mathrm{NAD}(\mathrm{P}) \mathrm{H}$ oxidases and reactive oxygen species in vascular oxygen sensing mechanisms. Respir. Physiol. 115, 229-238.

Wyatt, C.N., Peers, C., 1995. $\mathrm{Ca}^{2+}$-activated $\mathrm{K}^{+}$channels in isolated type I cells of the neonatal rat carotid body. $\mathrm{J}$. Physiol. London 483, 559-565.

Wyatt, C.N., Weir, E.K., Peers, C., 1994. Diphenyleneiodonium blocks $\mathrm{K}^{+}$and $\mathrm{Ca}^{2+}$ currents in type I cells isolated from neonatal rat carotid body. Neurosci. Lett. 172, $63-$ 66.

Youngson, C., Nurse, C., Yeger, H., Cutz, E., 1993. Oxygen sensing in airway chemoreceptors. Nature 365, 153-155.

Yuan, X.J., Goldman, W.F., Tod, M.L., Rubin, L.J., Blaustein, M.P., 1993. Hypoxia reduces potassium currents in cultured rat pulmonary but not mesenteric arterial myocytes. Am. J. Physiol. 264, L116-L123.

Yuan, X.J., Wang, J., Juhaszova, M., Golovina, V.A., Rubin, L.J., 1998. Molecular basis and function of voltage-gated $\mathrm{K}^{+}$channels in pulmonary arterial smooth muscle cells. Am. J. Physiol. 274, L621-L635.

Zhang, F., Carson, R.C., Zhang, H., Gibson, G., Thomas, H.M., 1997. Pulmonary artery smooth muscle cell $\left[\mathrm{Ca}^{2+}\right]_{\mathrm{i}}$, and contraction; responses to diphenyleneiodonium and hypoxia. Am. J. Physiol. 273, L603-L611.

Zhu, H., Qiu, H., Yoon, H.W., Huang, S., Bunn, H.F., 1999. Identification of a cytochrome b-type NAD(P)H oxidoreductase ubiquitously expressed in human cells. Proc. Natl. Acad. Sci. USA 96, 14742-14747. 